\title{
Deformation Control Monitoring of Basement Excavation at Field Construction Site: A Case of Hydraulic Servo Steel Enhancement Geotechnology
}

\author{
Horris K. Nangulama $\mathbb{i D}^{1,2}$ and Zhou Jian $\mathbb{D}^{1}$ \\ ${ }^{1}$ Research Centre of Coastal and Urban Geotechnical Engineering, Zhejiang University, Hangzhou 310058, China \\ ${ }^{2}$ Department of Mining Engineering, Malawi University of Business and Applied Sciences, Blantyre 312225, Malawi \\ Correspondence should be addressed to Zhou Jian; zjelim@zju.edu.cn
}

Received 8 November 2021; Revised 13 January 2022; Accepted 31 January 2022; Published 25 February 2022

Academic Editor: Jia-wen Zhou

Copyright (c) 2022 Horris K. Nangulama and Zhou Jian. This is an open access article distributed under the Creative Commons Attribution License, which permits unrestricted use, distribution, and reproduction in any medium, provided the original work is properly cited.

\begin{abstract}
This study presents two field cases of deep excavation using the hydraulic servo geotechnology as an enhancement to the lateral support. The first excavation process was preceded with numerical simulation to investigate the deformation of excavation pit with and without servo geotechnology. Optimised axial loading capacities from the numerical simulation were adopted at the actual excavation site. On the second excavation site, servo geotechnology was applied directly on the excavation process during actual construction without prior numerical simulation. The results showed that the servo steel support geotechnology restrained above $70 \%$ of lateral displacements of the excavated walls, and ground surface influence zone settlements were kept within the acceptable warning limits. Prior application of the numerical simulation before field excavation optimised axial loads and kept the deformation caused by excavation within project limits. The numerical simulation of servo geotechnology deformation control capacity for deep excavation projects is validated, and this study provides a practical and significant reference on similar projects.
\end{abstract}

\section{Introduction}

The advancement in geotechnical knowledge has led to the development of enhanced forms of underground construction for metro stations and high-rise buildings. The underground construction process requires deep basement excavation to specified depths. The deep excavation process comes with the challenge of deformation of the excavation pit and adjacent facilities due to the inadequate capacity of the traditional lateral support systems $[1,2]$. The safety of the surrounding environment is threatened whenever the deformation occurring caused by excavation is not reasonably restrained [3-7]. Therefore, an in-depth study of the lateral support system is required to improve on the lateral load resistance of the support members on excavation sites.

To solve a deep excavation-induced deformation challenge, several researchers have adopted steel bracing as an excavation internal support system [8-14]. Their efforts have shown the rational and effectiveness of steel bracing in deep basement excavation-induced displacement control. Specifically, Wang [8] and $\mathrm{Wu}$ and Yanxia [9] obtained the excavation-induced displacements in the range of $40-125 \mathrm{~mm}$ when steel bracing was used on different deep excavation projects of depth ranging over $10 \mathrm{~m}$. However, extra-sized steel sections had to be used, which increased the cost and the bracing labour to meet the required displacement limits imposed on the projects. Studies reported by Nicotera and Russo [12] and Benin et al. [13] adopted the steel bracing to support a deep foundation pit in soft rock and managed to reduce the excavation-induced displacement by $33 \%$ on average as compared with using other support members such as concrete struts. Hwang et al. [14] explained that, with the adoption of preloaded steel bracing as a deep excavation internal support structure, the induced deformation of the excavation is controlled to the extent of the predefined stiffness of the steel bracing support. The 
predefined steel stiffness cannot be increased in a loaded condition [3]. The steel bracing loses axial force in unexpected circumstances where the lateral load exceeds the support stiffness [11]. Eventually, the occurring deformation exceeds the standard limits [1]. This then could lead to construction challenges as well as endangering the adjacent structures $[5,7]$.

Steel bracing support stiffness enhanced by the hydraulic servo system has been reported by some researchers lately [15-19]. Specifically, Di et al. [15] investigated the deformation control mechanism of steel bracing with servo support and steel bracing without servo support based on simulated measured data. They divided the excavation pit into two parts. The first part was supported with steel bracing alone, while the second one was supported with a servo steel enhanced system. They found that the steel bracing alone in the excavation pit, which was without servo, exhibited a maximum of $86.7 \%$ axial force loss. In another study, PLAXIS 3D commercial finite element software was used by Ye et al. [20]. They analysed the basement excavation-induced deformation with respect to the steel bracing support system during the excavation process. Their measurements demonstrated that the steel bracing support without servo exhibited more than 65\% loss in axial loading capacity. Ming-Guang et al. [18] adopted the FLAC3D commercial software program for a case study on the Taipei National Enterprise Centre (TNEC). The deep excavation was numerically modelled to assess the effectiveness of hydraulic servo steel-supported excavation-induced deformation control, and their results were consistent with the determinations of Di et al. [15] and Ye et al. [20].

Furthermore, Ming-Guang et al. [18] pointed out that the application of servo method in deep excavations is based on engineers' experience and depends wholly on the available commercial software programs such as PLAXIS 3D and FLAC3D. Servo geotechnology is affected by slenderness ratio of steel struts, cross-section shape of steel struts, end conditions of steel struts, geometry of excavation, earth retaining wall type, construction procedure, and servo axial load application process [21]. Controlled experimental work for analytical-based solution to comprehensively consider these factors is a challenge [16]. Thus, simple and practical experimental-based analytical solutions cannot fully predict the excavation-induced deformation for servo method application [16]. Even though numerical simulation is capable of properly modelling the excavation complexity and the forenamed factors, the servo steel geotechnology support modelling process requires extensive computations and the simulation procedure in itself is complicated in practice [18]. The precision of numerical simulation is significantly affected by the choice of parameters. The preferred parameters primarily depend on the test method and are practically difficult to determine [19]. Comparatively, field construction site cases provide a suitable approach and first-hand experience to explore the servo steel supported system in excavation-induced deformation control of the excavation pit and surrounding environment [17]. Presently, there are few studies on the servo geotechnology application in deep excavation, and the limited available studies are based on numerical simulation [19]. With the process of urbanization, there are more deep excavation projects adjacent to structures and a strict requirement for excavation-induced deformation control. Thus, research regarding this phenomenon is still required. Therefore, this research takes two actual field projects and seeks to augment the actual field construction site applications of servo geotechnology with the numerical results to confirm the strength of servo method in deformation control caused by excavation in soft soil urban environment.

In this paper, case studies of two real field construction site application of hydraulic servo steel enhanced support geotechnology were carried out. The two construction site processes were monitored. The results from actual field works were compared well with previous research works based on numerical simulations on analysing the capacity of servo geotechnology enhanced supported system. In the first case scenario, a $16.5 \mathrm{~m}$ deep excavation of a subway station "Shenzhen Metro Rail Transit Line 12" (SMRTL_12) project in Shenzhen city, China, was analysed by measuring the excavation pit displacement with respect to the application of servo steel axial loading lateral support capacities from the numerical simulation results. The second case study was a $14.2 \mathrm{~m}$ deep basement excavation of "Triumph Unit" (TU) high-rise building block project in Hangzhou city, China. The field study was carried out by observing the actual displacement with respect to the inclusion of servo geotechnology directly at the construction site during the excavation works.

\section{The Hydraulic Servo Capacity Steel Enhancement Geotechnology}

A deep braced excavation commonly consists of a retaining wall and lateral support such as steel struts. The lateral support is enhanced by the hydraulic servo system for the increased axial loading capacity. Figure 1 shows the stressstrain curve of a low carbon steel strut under typical phases of deformation when loaded to failure. With the initial stage of loading, the steel experiences elastic deformation up to the yield strength point. As the steel stress goes beyond yield point, it reaches the ultimate strength point. Beyond this point, the steel reduces in capacity and fractures. To overcome this phenomenon, the servo geotechnology is included to the steel bracing support in this study to increase the composite capacity of the lateral support system without increasing the steel support section.

Currently, the hydraulic servo geotechnology application in deep excavation projects is limited due to the potential high cost of implementation [21]. However, the application of servo system gives the added advantage of reducing self-weight of the support system. The combined

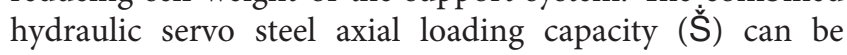
expressed as follows:

$$
\breve{S}=F_{y} A_{s s}+\widehat{W} \ddot{Y}
$$

where $F_{y} A_{s s}$ represents a loading capacity of a preloaded steel, with $F_{y}$ denoting the yield stress of steel and $A_{s s}$ 


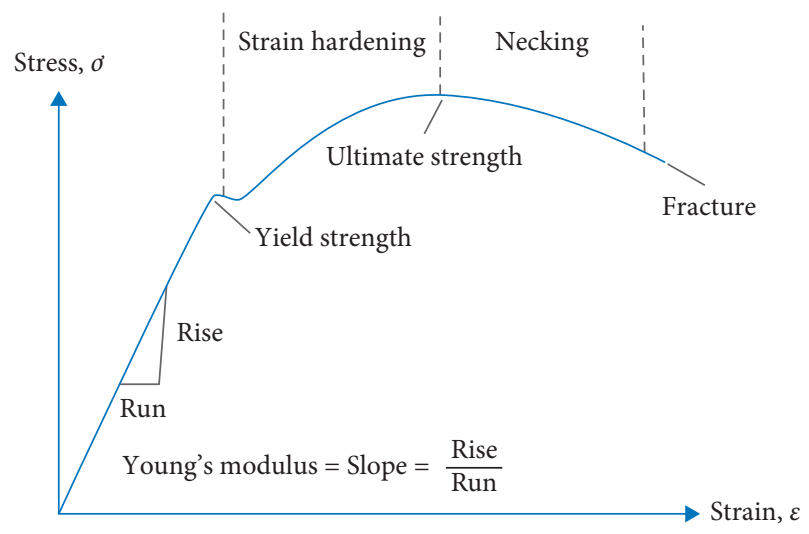

Figure 1: Typical low carbon steel stress-strain curve.

representing an effective cross-section area of steel, and $\widehat{W} \ddot{Y}$ is a loading capacity due to the hydraulic servo.

Servo geotechnology comprises an automatic controlled computerised unit and a hydraulic module. The hydraulic module contains a hydraulic jack together with a hydraulic pump station. The hydraulic jack is set between the basement excavation pit wall and the end of steel bracing. The hydraulic pump station has a pressure transmitting system. The pressure transmitting system is connected to a computerised unit via an adjustable connector. Figure 2 shows the field application arrangement and working principle of the servo steel system linked to a computerised control system and station. Figure 3 shows the schematic diagram of the servo system hydraulic jack pressed between the retaining wall and the end of steel bracing support.

From Figure 3, $P_{s}$ symbolizes the supply pressure and is constant and $P_{r}$ stands for the feedback pressure. Then, the equation of the servo inertial load can be dynamically expressed as

$$
\widehat{W} \ddot{Y}=P_{L} A_{h j}-F_{f}+F_{e},
$$

where $\hat{W}$ and $\ddot{\gamma}$ represent the mass of retaining wall and retaining wall displacement, respectively. $P_{L}=P 1-P 2$ depicts the load pressure of hydraulic jack with $P 1$ and $P 2$ denoting pressures within two chambers of the jack. $A_{h j}$ is the ram area of the jack. Thus, force inside the jack is pressure multiplied by area. $F_{e}$ symbolizes the unexpected loads and other external forces or disturbances, while $F_{f}$ is a friction force and can be given as

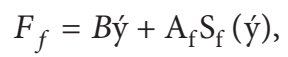

where $B$ depicts a viscous friction coefficient, $A_{f}$ is a constant coefficient, and $S_{f}(y)$ is a continuous function which denotes the change of retaining wall position.

Therefore, $P 1$ and $P 2$ can be described as

$$
\begin{aligned}
& P 1=\frac{\breve{e}}{V_{1}}\left(-A y ́-\mathrm{K}_{\mathrm{t}} \mathrm{P}_{\mathrm{L}}+\mathrm{Q}_{1}+\mathrm{q}_{1}\right),
\end{aligned}
$$

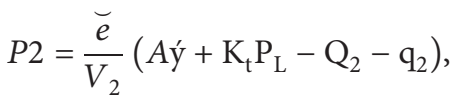

where $V_{1}$ and $V_{2}$ represent the volumes of the hydraulic jack chambers, $\breve{e}$ denotes the elastic modulus of hydraulic oil, and $K_{t}$ depicts the coefficient of total internal leakage of hydraulic jack and is related to $P_{L} \cdot q_{1}$ and $q_{2}$ model the errors, while $Q_{1}$ and $Q_{2}$ symbolise the supply and feedback flow rate, respectively. Therefore, $Q_{1}$ and $Q_{2}$ can be expressed as

$$
\begin{aligned}
& Q_{1}=N_{t} U\left[\operatorname{sign}(U) \sqrt{P_{s}-P_{L}}+\operatorname{sign}(-U) \sqrt{P 1-P_{r}}\right], \\
& Q_{2}=N_{t} U\left[\operatorname{sign}(U) \sqrt{P 2-P_{r}}+\operatorname{sign}(-U) \sqrt{P_{s}-p^{2}}\right],
\end{aligned}
$$

where $N_{t}$ represents the gain in the total flow capacity and $U$ stands for the controller output (adjustable connector) which is linked to the computerised control station. Therefore, sign $(U)$ can be defined as

$$
\operatorname{sign}(U)= \begin{cases}0, & \text { if } U<0, \\ 1, & \text { if } U \geq 0\end{cases}
$$

Thus, the computerised control station monitors the retaining wall displacement $\ddot{\gamma}$ to trace any desired wall displacement as intimately as possible while providing feedback through an adjustable connector, $U$, which controls the inertial load. Then, the combined steel and servo load lateral support in (1) works together to control the deformation within the set limit. When this limit is exceeded and the retaining wall moves to the inside of the excavation pit, then the support loading capacity is raised in an automatic control system module via an adjustable connector, $U$. If the retaining wall moves away from the excavation pit, then the set support loading capacity is reduced, hence controlling the wall deformation within acceptable project warning limit.

One of the major advantages of servo capacity steel enhancement geotechnology application is that it increases the lateral support capacity through the application of extra support axial loading capacity. However, the servo support system application has some disadvantages. The timing of loading of servo steel bracing is based on engineers' judgement [18]. In preloaded situations, the servo can cause puncture localised deformation when excess load is applied. If the servo load is applied after the steel strut has passed the ultimate loading stage, then the effect of the servo load cannot be optimised and the expected support capacity may not be reached [17]. The effect of servo steel enhanced support geotechnology on actual construction site displacement control is not comprehensive. This is because of the limited field construction site application of servo geotechnology [19].

\section{Analysis of SMRTL_12 Subway Station Excavation Project: A Case of Numerical Simulation and Field Study}

3.1. Project Description. Hydraulic servo geotechnology applied to the SMRTL_12 subway station excavation pit in Shenzhen city, China, was investigated in this section. This case was preferred for analysis because the excavated pit was only $7.8 \mathrm{~m}$ away from a bridge pile group foundation. The high-rise buildings and pipelines were within the enclave of 


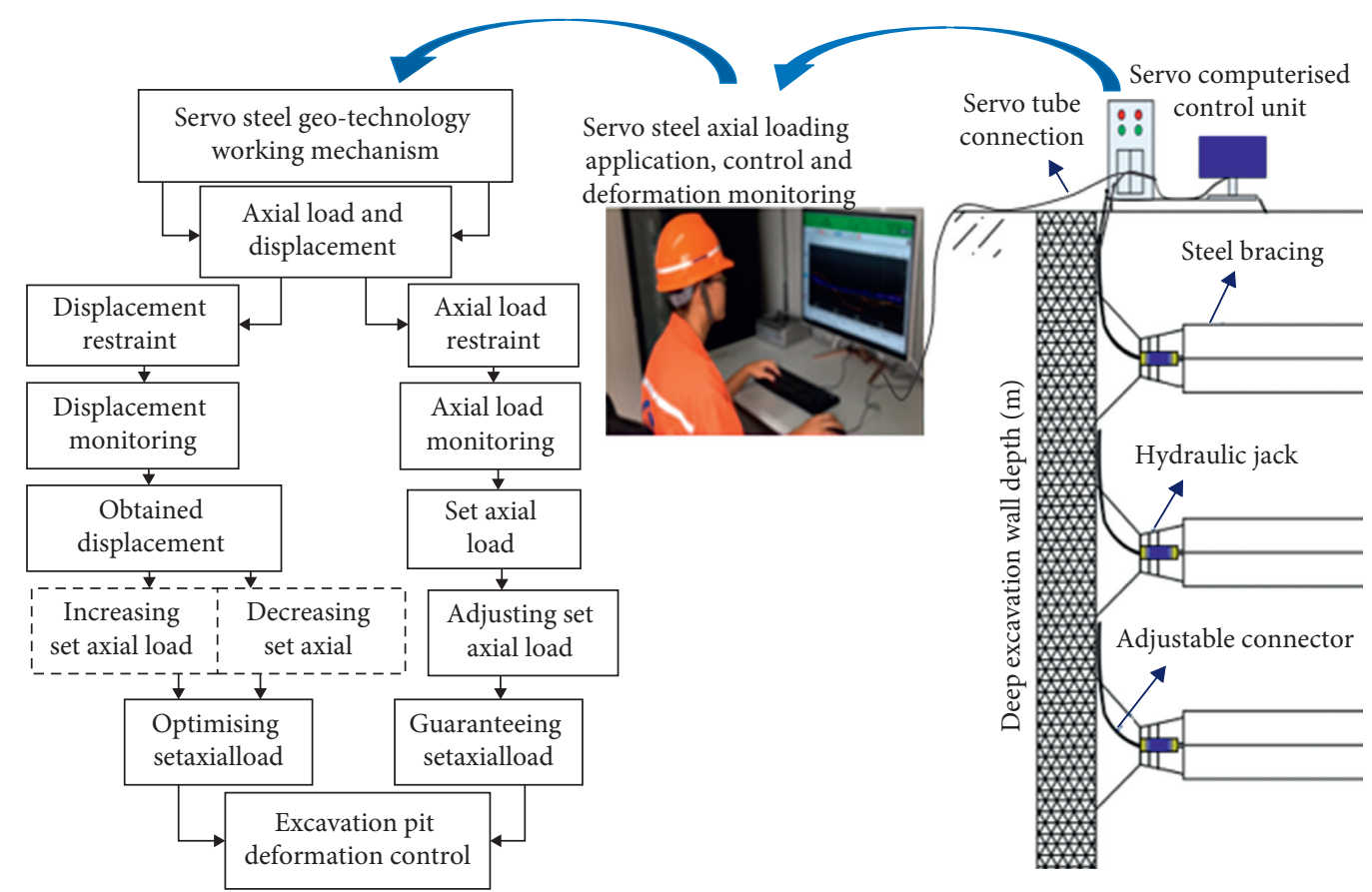

Figure 2: Field construction site application arrangement showing the working principle and mechanism of servo steel enhancement geotechnology.

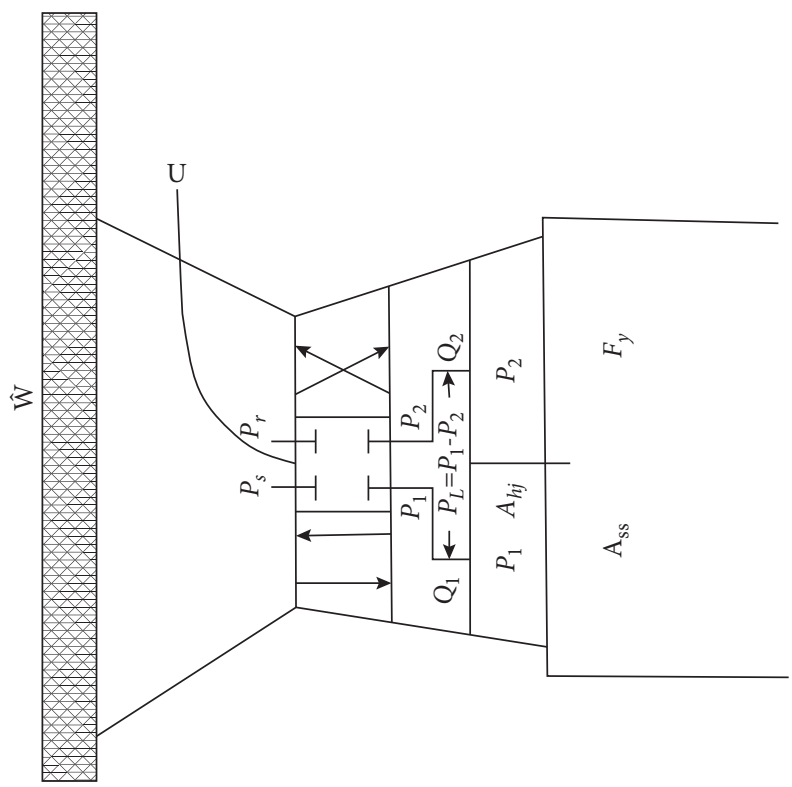

Figure 3: Schematic diagram of the servo system hydraulic jack pressed between the retaining wall and the end of steel bracing support.

the excavation. Hence, there is a strict requirement for the safety of the surrounding environment. To understand the behaviour of subway excavation prior to actual excavation, numerical simulation was performed. The load carrying capacity of the support system at various levels of excavation was optimised during the simulation. Optimal servo axial loading capacities were adopted and applied to the actual excavation.

The subway excavation pit type was a braced, narrowrectangular-shaped underground excavation, with a depth of $16.5 \mathrm{~m}$, length of $230.5 \mathrm{~m}$, and standard width of $21.1 \mathrm{~m}$. It passed through a $14.1 \mathrm{~m}$ overhead height of GuangzhouDongguan-Shenzhen intercity railway line which was under construction. Figure 4 shows the plan view of project location and surrounding structures to the excavation pit. Project construction requirement for the maximum wall displacement was $0.15 \%$ of $\mathrm{H}(16.5 \mathrm{~m}$; representing $25 \mathrm{~mm}$ ). $\mathrm{H}$ refers to the excavation depth. The warning limits for retaining wall shear force, axial force, and bending moment were $3000 \mathrm{kN}, 1200 \mathrm{kN}$, and 


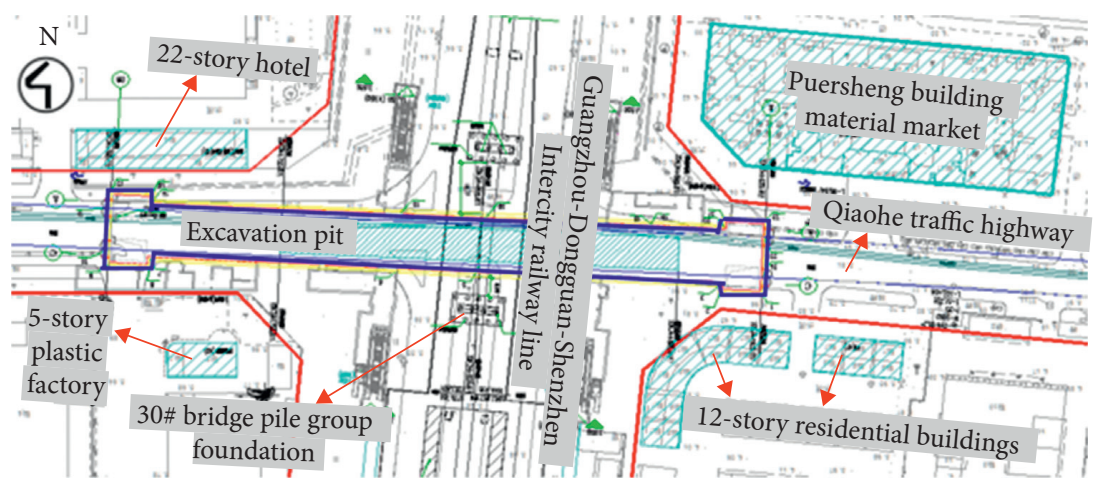

FIGURE 4: Plan view of the subway station project location.

$800 \mathrm{kN}-\mathrm{m}$, respectively. The maximum ground surface settlement limit was $0.06 \%$ of $\mathrm{H}(16.5 \mathrm{~m}$; representing $10 \mathrm{~mm})$. The ground surface settlement influence zone limit was $1.09 \%$ of $\mathrm{H}(16.5 \mathrm{~m}$; representing $18 \mathrm{~m})$. The allowable displacement limit on adjacent 30\# bridge pile group foundation was $3.0 \mathrm{~mm}$ maximum. The project standards conformed to various technical codes for excavation pit construction and protection of adjacent structures in railway transit urban environment [22-27].

Soil samples were obtained from the site by the drilling and sample survey method. A total of 46 machine drill holes were arranged at the sides and corners of the project site [28]. Laboratory soil tests such as Atterberg limit, plasticity index, and California bearing ratio as well as the in-situ dynamic penetrometer test, standard penetration test, and single-hole shear wave velocity test were performed on the soil samples. According to the test results, the soil stratum within the depth of $62 \mathrm{~m}$ has primarily soft silt to silty clayey properties, as shown in Tables 1 and 2 .

\subsection{The Numerical Model}

3.2.1. Procedure. The excavation and support process was modelled in PLAXIS 3D FEM software, version 20.0. The working model was $310 \mathrm{~m}$ long, $150 \mathrm{~m}$ wide, and $62 \mathrm{~m}$ deep. Model top boundary condition was freely laid. Model bottom boundary condition was fixed, and lateral boundary condition was entirely placed on normal axis direction.

The HS-small material property was preferred as a soil constituent model, as shown in Tables 1 and 2. This was because the HS-small model takes into account stress dependence, thereby providing nonlinear elastic unloading/ reloading behaviour [20]. It provides both qualitative and quantitative realistic deformation pattern and good bottom heave independent of model depth. This is attributed to small strain stiffness behaviour and more realistic settlements through behind retaining wall that is narrower and deeper [20]. The adopted numerical model parameters are given in Table 3 , the numerical modelling steps are presented in Table 4, and the whole numerical model overview is shown in Figure 5.

\subsection{Numerical Simulation Results}

3.3.1. Steel Bracing Support Alone. Figures 6-9 show the calculated wall displacement, structural forces, ground surface settlement profile, and the deformation profile of 30\# bridge pile, respectively, when the excavation pit was supported with the steel struts alone. The maximum wall displacement equalled $0.51 \%$ of $\mathrm{H}(16.5 \mathrm{~m}$; representing $84 \mathrm{~mm}$ ), as shown in Figure 6. The maximum wall shear force, axial force, and bending moment were $3240 \mathrm{kN}$, $2100 \mathrm{kN}$, and $1250 \mathrm{kN}-\mathrm{m}$, respectively, as depicted in Figure 7 . The maximum ground surface settlement was $12.1 \mathrm{~mm}$, and ground surface settlement influence zone reached $27.2 \mathrm{~m}$ behind the wall, as presented in Figure 8. The maximum displacement on 30\# bridge pile was $3.4 \mathrm{~mm}$, as shown in Figure 9.

From Figures 6-9, the results exceeded project acceptable warning limits with the application of steel bracing support alone. Thus, the project model was not sufficient based on calculated results at the limit of project deformations. Hence, the servo method is included to enhance the load carrying capacity of steel support members.

\subsubsection{Steel Bracing Support with Servo Axial Load Capacity} Enhancement. During the numerical modelling, the servo load was modelled as a point load element which was pressed between the end of steel bracing and the retaining wall to enforce the lateral support mechanism [18]. The servo working principle in a numerical model involved setting initial estimated axial load capacity at current excavation stage and calculating the model to obtain corresponding deformation of support structure and adjacent structures. The corresponding deformation was then compared with the acceptable limit, optimised or adjusted, and recalculated until the satisfactory results were obtained.

(1) Retaining Wall Lateral Displacement. Figure 10 shows the calculated wall displacement results due to the inclusion of the servo method in a numerical modelling analysis. From Figure 10, the optimum servo steel axial loading capacities on wall displacement control were determined after 4 case attempts. 
TABLE 1: Soil parameters.

\begin{tabular}{|c|c|c|c|c|c|c|}
\hline Soil layer no. & Soil layer name & Average thickness (m) & $\begin{array}{l}\text { Unit weight } \gamma \\
\left(\mathrm{kN} / \mathrm{m}^{3}\right)\end{array}$ & $\begin{array}{c}\text { Cohesive force } C \\
(\mathrm{kPa})\end{array}$ & $\begin{array}{c}\text { Internal friction angle } f \\
\left({ }^{\circ}\right)\end{array}$ & $\begin{array}{l}\text { Poisson's } \\
\text { ratio }\end{array}$ \\
\hline (1) & Miscellaneous fill & 9.9 & 18.5 & 9.3 & 22.0 & 0.21 \\
\hline (2) & Silt & 5.4 & 17.4 & 7.5 & 9.0 & 0.3 \\
\hline (3) & Silt & 13.8 & 18.9 & 18.8 & 23.9 & 0.3 \\
\hline (4) & Silty clay & 2.7 & 19.3 & 25.0 & 15.0 & 0.24 \\
\hline (5) & Sandy clay & 11.0 & 18.5 & 27.0 & 21.0 & 0.20 \\
\hline (6) & Weathered granite rock & 22.1 & 21.0 & 536.0 & 34.1 & 0.17 \\
\hline
\end{tabular}

TABLE 2: Soil parameters.

\begin{tabular}{|c|c|c|c|c|c|c|}
\hline \multirow[b]{2}{*}{ Soil layer no. } & \multirow[b]{2}{*}{ Soil layer name } & \multirow[b]{2}{*}{ Average thickness (m) } & \multicolumn{3}{|c|}{ Stiffness } & \multirow[b]{2}{*}{$\begin{array}{l}\text { Permeability coefficient } K \\
(\mathrm{~m} / \mathrm{d})\end{array}$} \\
\hline & & & $\mathrm{E} 50^{\mathrm{ref}}\left(\mathrm{kN} / \mathrm{m}^{2}\right)$ & Eoed $^{\text {ref }}\left(\mathrm{kN} / \mathrm{m}^{2}\right)$ & $\begin{array}{c}\text { Eur }{ }^{\text {ref }} \\
\left(\mathrm{kN} / \mathrm{m}^{2}\right)\end{array}$ & \\
\hline (1) & Miscellaneous fill & 9.9 & $2.325 \mathrm{e}^{4}$ & $3.123 \mathrm{e}^{4}$ & $9.957 \mathrm{e}^{4}$ & 21.4 \\
\hline (2) & Silt & 5.4 & $2.23 \mathrm{e} 4$ & $2.791 \mathrm{e} 4$ & $9.474 \mathrm{e} 4$ & 8.8 \\
\hline (3) & Silt & 13.8 & $2.23 \mathrm{e} 4$ & $2.791 \mathrm{e} 4$ & $9.474 \mathrm{e} 4$ & 8.8 \\
\hline (4) & Silty clay & 2.7 & $3.24 \mathrm{e} 4$ & $3.750 \mathrm{e} 4$ & $11.24 \mathrm{e} 4$ & 5.0 \\
\hline (5) & Sandy clay & 11.0 & $3.0 \mathrm{e} 4$ & $3.310 \mathrm{e} 4$ & $10.93 \mathrm{e} 4$ & 0.1 \\
\hline (6) & Weathered granite rock & 22.1 & $3.04 \mathrm{e} 4$ & $3.451 \mathrm{e} 4$ & $11.55 \mathrm{e} 4$ & 1.6 \\
\hline
\end{tabular}

TABle 3: Numerical model parameters.

\begin{tabular}{|c|c|c|c|}
\hline \multicolumn{4}{|c|}{ Parameters of plate element } \\
\hline Parameter & Name & Sheet pile wall & Units \\
\hline Behaviour & Type & $\begin{array}{c}\text { Elastic; } \\
\text { nonisotropic }\end{array}$ & - \\
\hline Thickness & $\mathrm{d}$ & 1.00 & M \\
\hline Height & $\mathrm{H}$ & 24.00 & M \\
\hline Unit weight & $\mathrm{Y}$ & 2.75 & $\mathrm{kN} / \mathrm{m}^{3}$ \\
\hline \multirow{2}{*}{ Young's modulus } & E1 & $14.60 \mathrm{E} 6$ & $\mathrm{kN} / \mathrm{m}^{2}$ \\
\hline & E2 & $73.00 \mathrm{E} 4$ & $\mathrm{kN} / \mathrm{m}^{2}$ \\
\hline Poisson's ratio & $\mathrm{v}$ & 0.20 & - \\
\hline \multicolumn{4}{|c|}{ Parameters of beam element } \\
\hline Parameter & Name & Steel strut & Units \\
\hline Material type & Type & Elastic & - \\
\hline Young's modulus & $\mathrm{E}$ & $210.00 \mathrm{E} 6$ & $\mathrm{kN} / \mathrm{m}^{2}$ \\
\hline Unit weight & $\mathrm{Y}$ & 78.50 & $\mathrm{kN} / \mathrm{m}^{3}$ \\
\hline \multirow[t]{2}{*}{ Cross-section area } & A & 0.008682 & $\mathrm{~m}^{2}$ \\
\hline & I1 & 0.00 & \\
\hline \multirow[t]{2}{*}{ Moment of inertia } & $\mathrm{I} 2$ & 0.000366 & $\mathrm{~m}^{4}$ \\
\hline & $\mathrm{I} 3$ & 0.0001045 & \\
\hline \multicolumn{4}{|c|}{ Parameters of embedded beam element } \\
\hline Parameter & Name & $\begin{array}{l}\text { 30\# bridge pile } \\
\text { group }\end{array}$ & Units \\
\hline Young's modulus & $\mathrm{E}$ & $30.00 \mathrm{E} 6$ & $\mathrm{kN} / \mathrm{m}^{2}$ \\
\hline Unit weight & Y & 8.00 & $\mathrm{kN} / \mathrm{m}^{3}$ \\
\hline Beam type & Predefined & $\begin{array}{l}\text { Massive } \\
\text { circular }\end{array}$ & \\
\hline Axial skin resistor & Type & Linear & \\
\hline Diameter & $\mathrm{d}$ & 2.00 & $\mathrm{~m}$ \\
\hline
\end{tabular}

In case 1 , the steel bracing was incorporated with a servo axial load of $2000 \mathrm{kN}$ capacity in all elevations. The initial applied $2000 \mathrm{kN}$ axial load was as estimated and provided by the project design institute. The maximum displacement of $0.23 \%$ of $\mathrm{H}(16.5 \mathrm{~m}$; representing $37 \mathrm{~mm})$ was obtained at case 1 , which declined by $56 \%$ as compared with maximum displacement calculated when the pit support was steel bracing alone. Although there was tremendous percentage reduction of displacement, the calculated maximum displacement exceeded the allowable limit. Thus, $2000 \mathrm{kN}$ servo load was only adopted at $-0.5 \mathrm{~m}$ elevation, where the displacement fell within the limit at case 1 , as demonstrated in Figure 10.

In case 2, the higher $2200 \mathrm{kN}$ servo load was incorporated at $-7.5 \mathrm{~m},-10.5 \mathrm{~m}$, and $-13.5 \mathrm{~m}$ elevations, while the $2000 \mathrm{kN}$ servo load was maintained at $-4.5 \mathrm{~m}$ elevation. The calculated maximum displacement was $0.18 \%$ of $\mathrm{H}(16.5 \mathrm{~m}$; representing $30 \mathrm{~mm}$ ), as shown in Figure 10. The maximum displacement had dropped by $64 \%$ when comparison is made with steel struts support alone. The displacement was exclusively within allowable limit at $-4.5 \mathrm{~m}$ and $-7.5 \mathrm{~m}$ elevations, and this limit was exceeded as excavation depth increased.

In case 3, the higher servo load of $2400 \mathrm{kN}$ was incorporated at $-10.5 \mathrm{~m}$ and $-13.5 \mathrm{~m}$ elevations where the displacement limit was exceeded at case 2 . Concurrently, the $2000 \mathrm{kN}$ and $2200 \mathrm{kN}$ axial load capacities were maintained at $-4.5 \mathrm{~m}$ and $-7.5 \mathrm{~m}$ stages, respectively, where the displacement fell within the limit at case 2 . The calculated maximum displacement was $0.164 \%$ of $\mathrm{H}$ ( $16.5 \mathrm{~m}$; representing $27 \mathrm{~mm}$ ), as shown in Figure 10. The maximum displacement had declined by $68 \%$ as compared with the displacement results obtained when the support was steel bracing alone. However, the maximum displacement at $-13.5 \mathrm{~m}$ and $-16.5 \mathrm{~m}$ elevations exceeded the allowable limit.

In case 4 , the higher $2600 \mathrm{kN}$ servo load was incorporated at $-13.5 \mathrm{~m}$ elevation only. The $2000 \mathrm{kN}, 2200 \mathrm{kN}$, and $2400 \mathrm{kN}$ servo loads remained unchanged at $-4.5 \mathrm{~m},-7.5 \mathrm{~m}$, and $-10.5 \mathrm{~m}$ elevations, respectively, where the displacement fell within the limit at case 3 . The calculated maximum displacement became $0.13 \%$ of $\mathrm{H}(16.5 \mathrm{~m}$; representing 
TABLE 4: Numerical modelling steps.

\begin{tabular}{lc}
\hline Step & Action \\
\hline 1 & Set up the adjacent $30 \#$ bridge pile group foundation. \\
2 & Set up retaining wall, interfaces, and $20 \mathrm{kN}$ working load [20]. \\
3 & Excavation to $-5.1 \mathrm{~m}$. \\
& Set the excavated area dry. Adapt pore pressure above the undrained layer by assuming the hydraulic condition and by interpolating \\
4 & the undrained layer. (Phreatic level behind retaining wall and below undrained layer remains unchanged since soil is blind to \\
5 & excavation.) \\
6 & Set up the first steel-servo support at $-4.5 \mathrm{~m}$. \\
7 & Excavation to $-8.1 \mathrm{~m}$. \\
8 & Repeat Step 4. \\
9 & Set up the second steel-servo support at $-7.5 \mathrm{~m}$. \\
10 & Excavation to $-11.1 \mathrm{~m}$. \\
11 & Repeat Step 4. \\
12 & Set up the third steel-servo support at $-10.5 \mathrm{~m}$. \\
13 & Excavation to $-14.1 \mathrm{~m}$. \\
14 & Repeat Step 4. \\
15 & Set up the fourth steel-servo support at $-13.5 \mathrm{~m}$. \\
16 & Excavation to $-16.5 \mathrm{~m}$ (formation level). \\
17 & Repeat Step 4. \\
18 & Construct $1.0 \mathrm{~m}$ bottom concrete slab at $-15.5 \mathrm{~m}$ as a waterproof curtain. \\
\hline
\end{tabular}

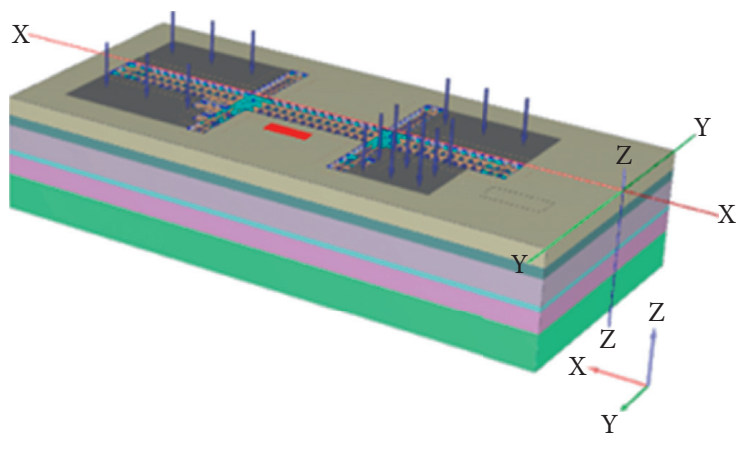

(a)

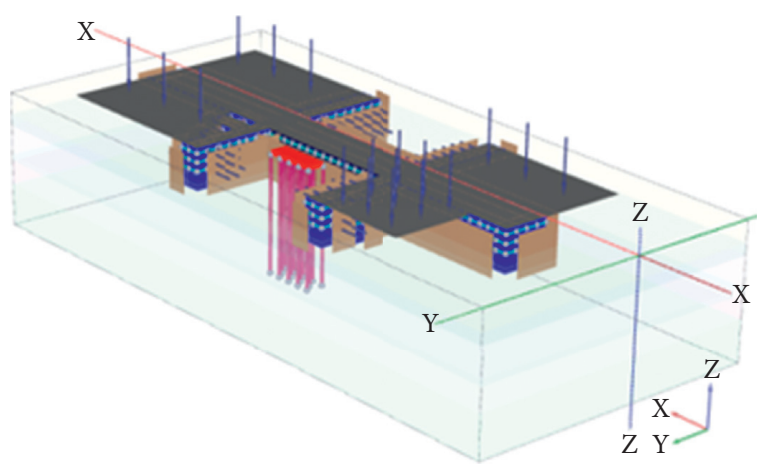

(b)

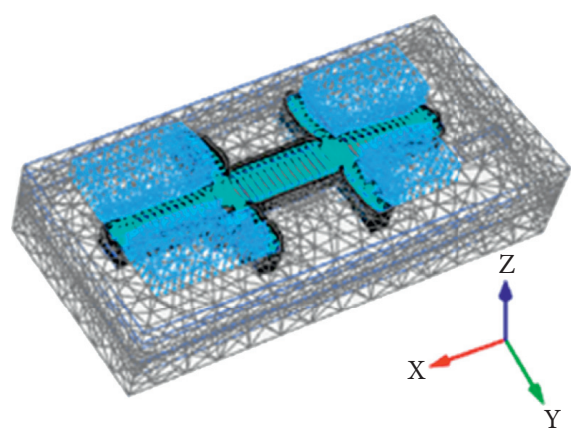

(c)

FIgURE 5: PLAXIS 3D numerical model overview. (a) Model. (b) Structure. (c) Mesh map.

$22 \mathrm{~mm}$ ), which declined by $74 \%$ compared with the calculated maximum displacement when the support was steel bracing alone. The calculated results satisfied the requirement at the limit of displacement of $0.15 \%$ of $\mathrm{H}(16.5 \mathrm{~m}$; representing $25 \mathrm{~mm}$ ). Thus, the inclusion of the servo method enhanced the wall displacement control at case 4 numerical calculation.
(2) Retaining Wall Structural Forces. The shear forces, axial forces, and bending moments of the retaining wall were investigated when the $2000 \mathrm{kN}, 2200 \mathrm{kN}, 2400 \mathrm{kN}$, and $2600 \mathrm{kN}$ axial loading support capacities were, respectively, applied at $-4.5 \mathrm{~m},-7.5 \mathrm{~m},-10.5 \mathrm{~m}$, and $-13.5 \mathrm{~m}$ elevations.

Figure 11 shows the calculated maximum shear force, axial force, and bending moment of $1270 \mathrm{kN}, 650 \mathrm{kN}$, and 


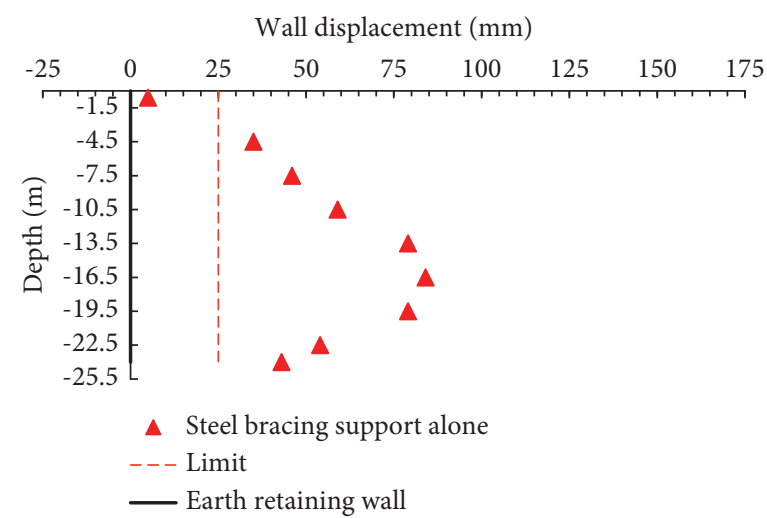

FIGURE 6: Influence of the application of steel bracing support alone on wall lateral displacement profile.

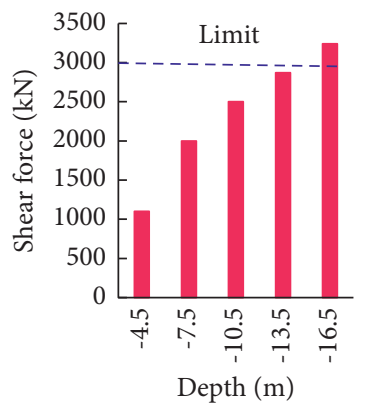

(a)

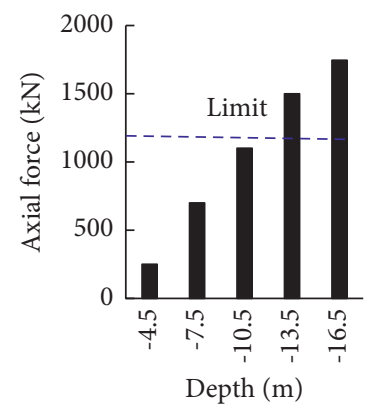

(b)

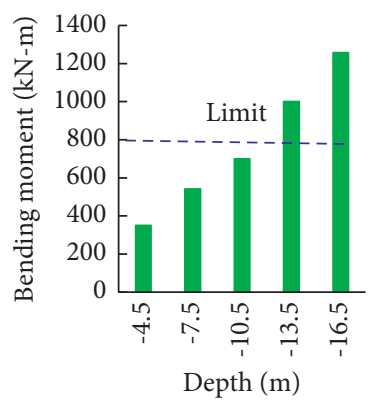

(c)

FiguRe 7: Influence of the application of steel bracing support alone on wall (a) shear force, (b) axial force, and (c) bending moment.

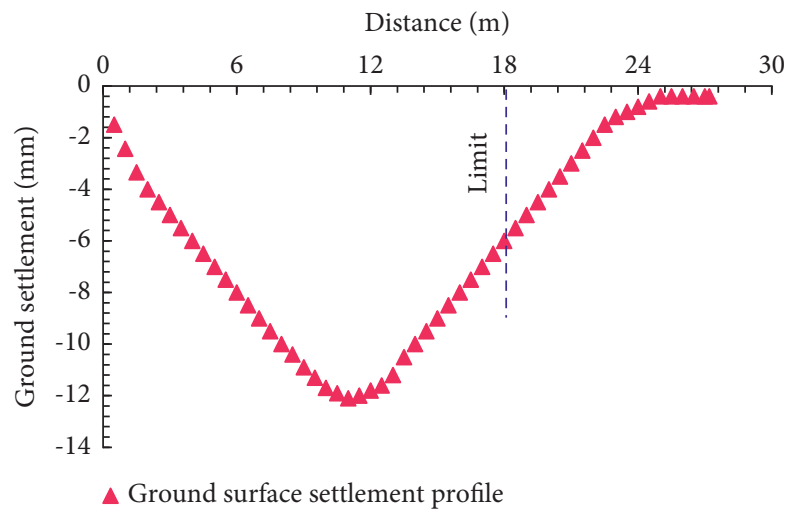

FiguRE 8: Influence of the application of steel bracing support alone on the profile of ground surface influence zone settlement.

$440 \mathrm{kN}-\mathrm{m}$, respectively. From Figure 11, we can see that the shear force, axial force, and bending moment fell under the project acceptable limits. The shear force had reduced by $60.8 \%$, the axial force had dropped by $69 \%$, and the bending moment had decreased by $71.6 \%$. Thus, the structural forces had declined significantly compared with the calculated structural forces when the support was steel bracing alone. Hence, the model was sufficient enough based on structural forces' dataset.

(3) Ground Surface Influence Zone Settlement. The ground surface influence zone settlement was investigated with the respective application of servo load capacities of
$2000 \mathrm{kN}, 2200 \mathrm{kN}, 2400 \mathrm{kN}$, and $2600 \mathrm{kN}$ at $-4.5 \mathrm{~m},-7.5 \mathrm{~m}$, $-10.5 \mathrm{~m}$, and $-13.5 \mathrm{~m}$ elevations. Figure 12 shows the calculated ground surface influence zone settlement profile.

From Figure 12, we can see that the maximum ground surface settlement was $5 \mathrm{~mm}$ and was within the project acceptable limit of $0.06 \%$ of $\mathrm{H}$ ( $16.5 \mathrm{~m}$; representing $10 \mathrm{~mm})$. The influence zone was kept at $17 \mathrm{~m}$ behind the wall as required. The maximum ground surface settlement had reduced by $59 \%$, and the settlement influence zone had dropped by $37.5 \%$. This was as compared with the calculated ground surface influence zone settlement profile when the support was steel bracing alone. Thus, with the application of 


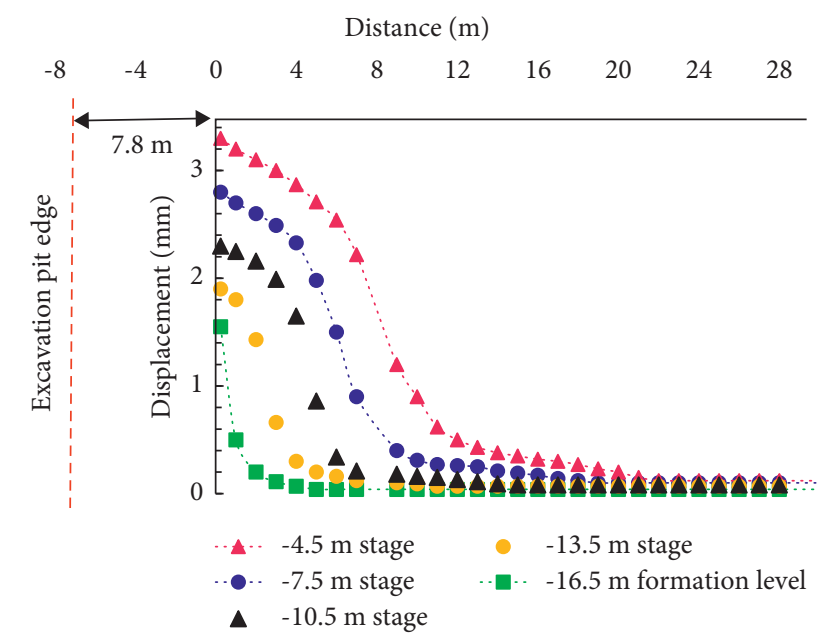

Figure 9: Relative ground displacement from 30\# bridge pile group foundation with the application of steel bracing support alone.

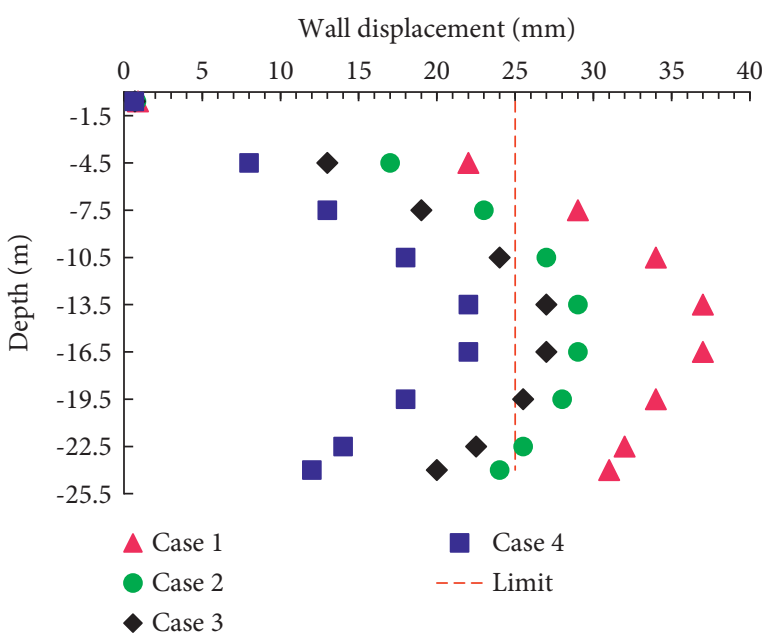

FIGURE 10: Influence of the application of steel bracing support with servo geotechnology axial loading capacity enhancement on wall lateral displacement profile in 4 case scenarios.

servo loads, the ground surface settlement and the influence zone were controlled desirably.

(4) Adjacent 30\# Bridge Pile Group Foundation. The next step was to investigate the deformation on the adjacent 30\# bridge pile if satisfactory due to the effect of the excavationinduced ground surface settlement profile. If not satisfactory, then the optimisation process was to be repeated with other set of servo loads until the requirement was met. This was done to examine the safety of a $7.8 \mathrm{~m}$ closest 30 \# bridge pile prior to the actual excavation.

Figure 13 shows that the 30 \# bridge pile experienced a maximum displacement of $0.015 \%$ of $\mathrm{H}(16.5 \mathrm{~m}$; representing $2.4 \mathrm{~mm}$ ), which declined by $29.4 \%$ as compared with the calculated maximum displacement when the support was steel bracing alone. The calculated maximum displacement was very minimal and within the project allowable limit. Thus, the project excavation posed almost negligible impact on the 30 \# bridge pile with the inclusion of the servo method [1]. This result agreed well with the finding of Ming-Guang et al. [18], which demonstrated the strong control capacity of servo steel geotechnology on surrounding environment relative deformation caused by excavation.

Therefore, the optimum servo steel bracing axial loading capacities were $2000 \mathrm{kN}$ at $-4.5 \mathrm{~m}$ excavation stage, $2200 \mathrm{kN}$ at $-7.5 \mathrm{~m}$ excavation stage, $2400 \mathrm{kN}$ at $-10.5 \mathrm{~m}$ excavation stage, and $2600 \mathrm{kN}$ at $-13.5 \mathrm{~m}$ excavation stage. With the application of the optimum results, the deformation caused by excavation was restrained as required. Moreover, Figure 14(a) shows the influence of the optimum axial load application on the whole project model displacement. Figure 14(b) shows the numerical model displacement pattern isosurface which details the inside of the soil model. The displacement pattern isosurface significantly demonstrated that there was unloading soil material behaviour. This phenomenon was mainly influenced by vertical unloading at excavation bottom depth and horizontal unloading behind the wall [20]. Vertical unloading behaviour of the soil was attributed to the influence of $20 \mathrm{kPa}$ working load, earthwork excavation, and lateral support application, eventually resulting to the lateral forces and exposure of retaining wall to earth and hydrostatic pressure. Moreover, the excavation pit was stable enough based on PLAXIS 3D analysis. Failure due to heaves was not encountered.

3.4. Actual Field Works at SMRTL_12 Subway Station Construction Site. Four steel bracing levels were erected as the internal support structure. The bracing was a straight steel tube support with a diameter of $609 \mathrm{~mm}$ and thickness of $16 \mathrm{~mm}$. It was horizontally and vertically spaced $10 \mathrm{~m}$ and $3 \mathrm{~m}$ apart in all elevations, respectively. The steel bracing had a stiffness of $500 \mathrm{MN} / \mathrm{m}$, resistance of $9000 \mathrm{kN}$, and adjustment coefficient of 1.0. It had movable ends for prestress application and was erected at $-4.5 \mathrm{~m},-7.5 \mathrm{~m},-10.5 \mathrm{~m}$, and $-13.5 \mathrm{~m}$ elevations. Optimum servo steel bracing axial loads of $2000 \mathrm{kN}, 2200 \mathrm{kN}, 2400 \mathrm{kN}$, and $2600 \mathrm{kN}$ as determined during numerical simulation were applied at each steel elevation, respectively.

The retaining structure construction preceded the steel servo support erection. It included the enclosed bored piles ( $11000 @ 1000$, length 24 m, C35).1019 (Ф850@600, length $23 \mathrm{~m}$ ) high-pressure rotary jet piles surrounded the excavation pit as waterproof curtain. For geotechnical condition, the soil strata at the site are shown in Tables 1 and 2. Figure 15 shows the profile of the excavation crosssectional view. Table 5 presents the actual excavation field works.

The excavation pit was instrumented with the inclinometer castings to trace the excavation-induced behaviours. Figure 16 shows the subway station excavation pit plan view, with the inclinometer castings buried in the retaining wall to measure the wall lateral displacement and ground movement behind the wall. The inclinometers were cautiously calibrated and were often checked to avoid measurement inaccuracy [29]. 


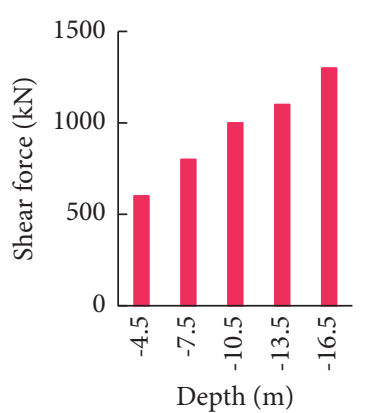

(a)

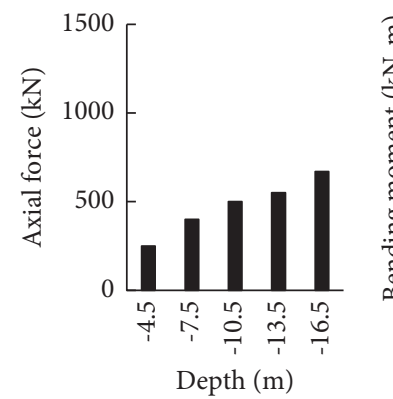

(b)

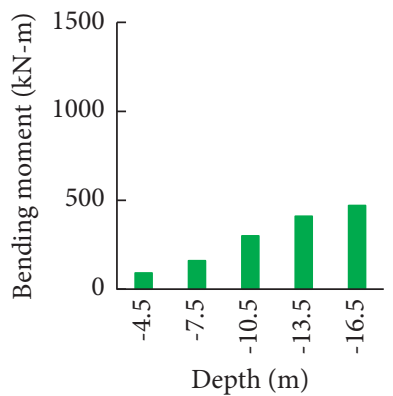

(c)

FIGURE 11: Influence of the application of steel bracing support with servo geotechnology axial loading capacity enhancement on wall (a) shear force, (b) axial force, and (c) bending moment.

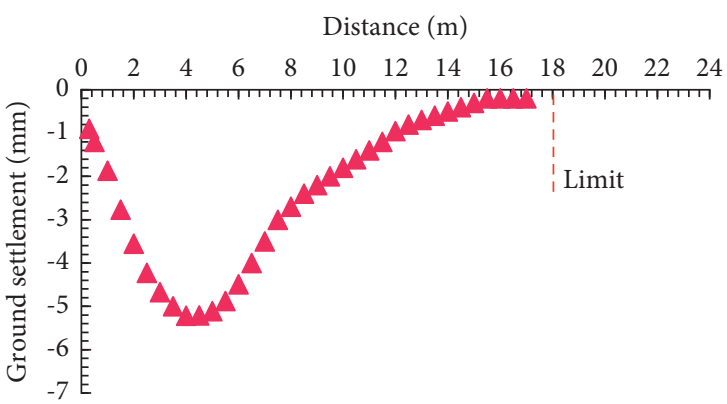

$\Delta$ surface settlement profile

FIgURE 12: Influence of the application of steel bracing support with servo geotechnology axial loading capacity enhancement on ground surface influence zone settlement profile.

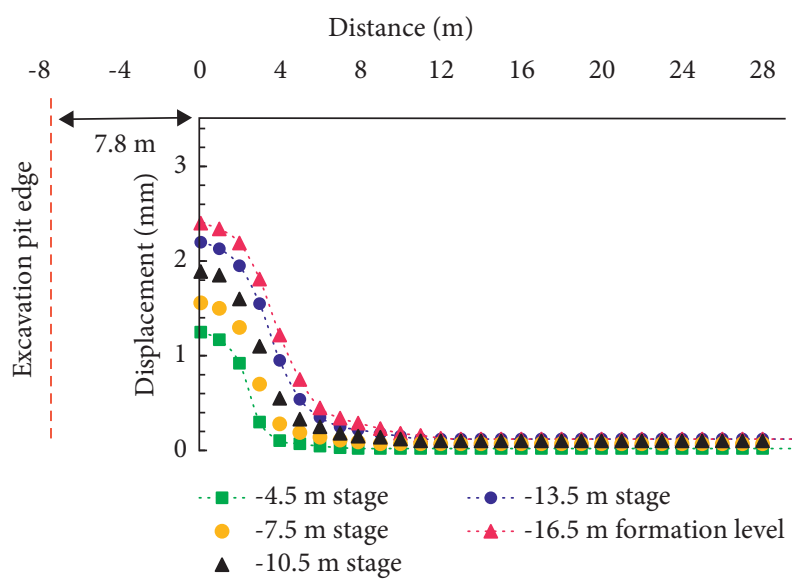

FIgURE 13: Relative ground displacement from 30\# bridge pile group foundation with the application of the servo steel geotechnology axial loading support capacity enhancement.

During the actual field study, only the influence of servo steel loading support application on the selected two inclinometer pile bodies' horizontal displacement and ground surface influence zone settlement profile was investigated. This was done to portray the strength of servo steel enhanced support geotechnology in deep excavation-induced displacement control on an actual construction site application basis. The influence of servo steel loading support application on retaining wall structural forces and on $7.8 \mathrm{~m}$ closest 30\# bridge pile group foundation was not investigated.

The ZQT21 and ZQT12 were preferred for monitoring analysis. The ZQT21 was opted to get the excavation pit 3D corner effect behaviour since it was established at the corner of the pit. The ZQT12 was preferred because it was adjacent to the $30 \#$ bridge pile group foundation. The proximity of 30\# bridge pile eventually helped in getting the actual maximum wall displacement due to the distribution of pressure in the soil mass which influenced the soil movement $[7,10]$.

3.4.1. Field Monitoring Results. Figure 17 shows the measured pile body cumulative horizontal displacement development pattern over the excavation stages of each of the two selected monitoring points. Figure 17(a) indicates that the ZQT21 experienced a maximum horizontal displacement of $0.099 \%$ of $\mathrm{H}(16.5 \mathrm{~m}$; representing $16.3 \mathrm{~mm})$ at $0.41 \mathrm{H}$ $(6.8 \mathrm{~m})$ elevation during earthwork excavation to $-13.5 \mathrm{~m}$ elevation. The minimal horizontal displacement on ZQT21 can be attributed to the excavation pit 3D corner effect behaviour resulting from the reduced displacement development inside the excavation area [7, 10]. Similarly, Figure 17(b) demonstrates that the ZQT12 experienced a maximum horizontal displacement of $0.109 \%$ of $\mathrm{H}(16.5 \mathrm{~m}$; representing $17.9 \mathrm{~mm}$ ) at the top of the pile during excavation advancement to $-13.5 \mathrm{~m}$ elevation. Moreover, the measured maximum horizontal displacement on both ZQT21 and ZQT12 satisfied this project requirement at the limit of displacement of $0.15 \%$ of $\mathrm{H}(16.5 \mathrm{~m}$; representing $25 \mathrm{~mm}$ ). The higher horizontal displacement on ZQT12 pile top can be attributed to the closeness of $30 \#$ bridge pile group foundation, thereby influencing the ground surface movement, which led to the distribution of pressure across the ground [10].

With the erection of servo steel axial load support in all elevations, the increase in horizontal displacement on both ZQT21 and ZQT12 stopped. The stoppage of pile bodies' cumulative horizontal displacement confirmed the strength of servo steel enhanced support geotechnology in restraining wall displacement caused by excavation. 


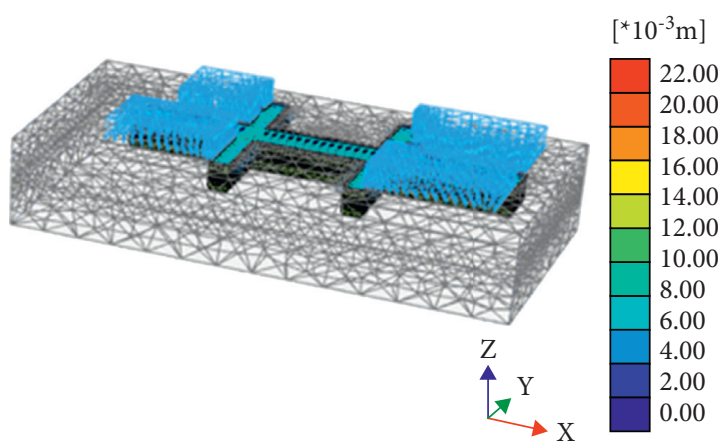

(a)

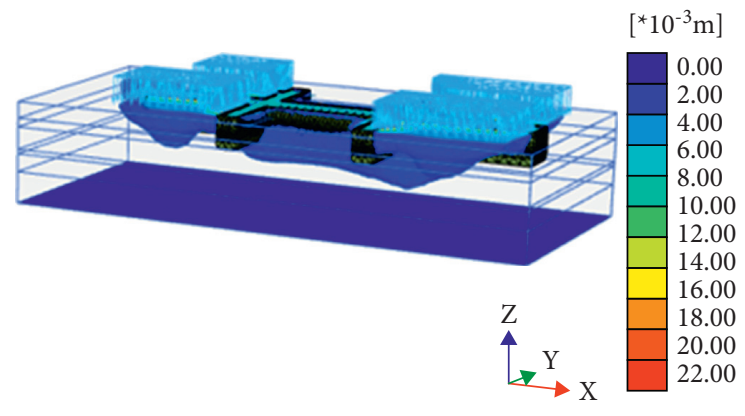

(b)

FIGURE 14: Influence of the application of optimum axial loading support capacities on the whole project model. (a) Total displacement. (b) Displacement isosurface.

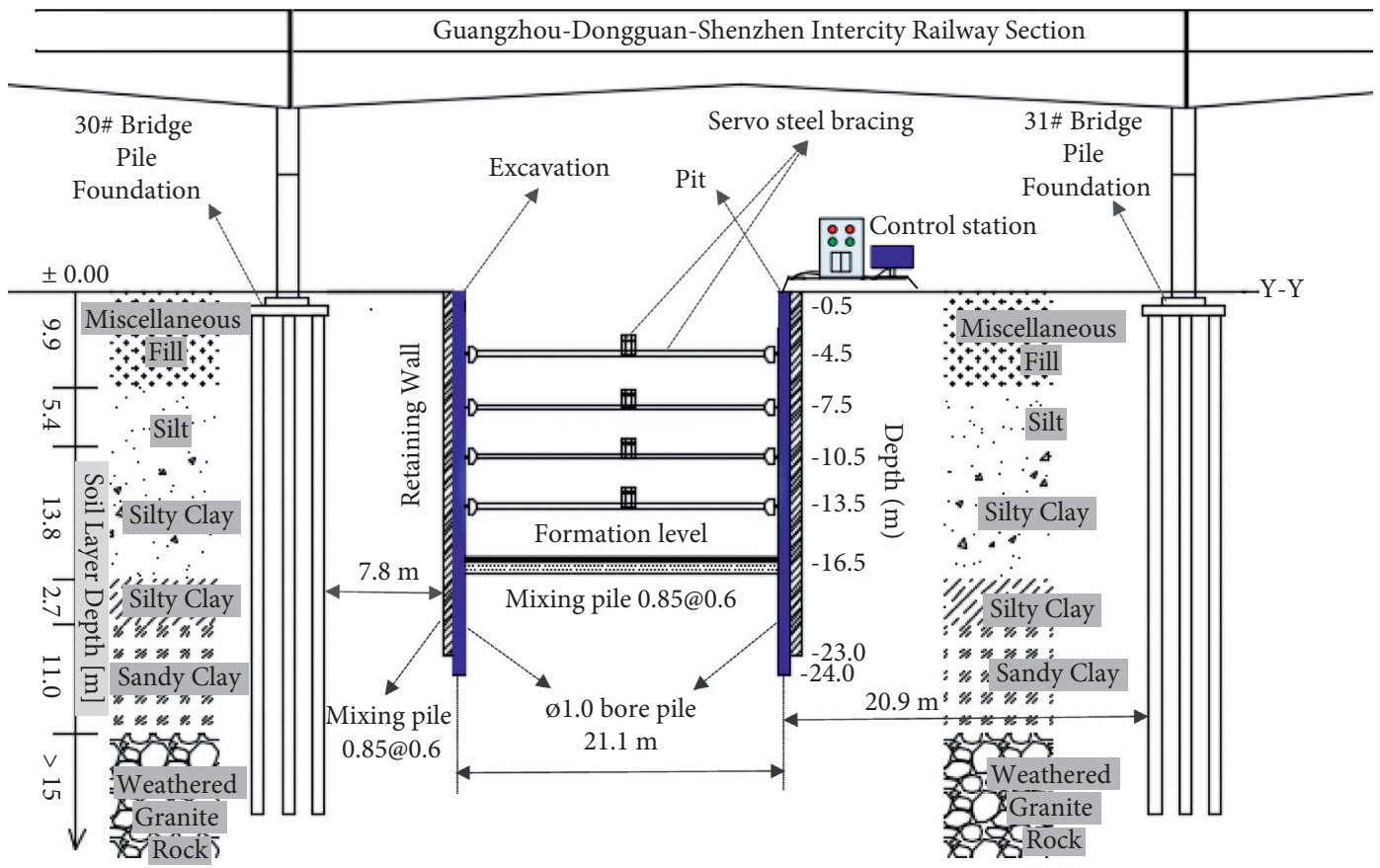

FiguRE 15: Shenzhen Line 12 subway station excavation pit profile showing cross-sectional view through Guangzhou-Dongguan-Shenzhen intercity railway section intersection.

TABLE 5: Subway station field excavation works.

\begin{tabular}{lcc}
\hline Construction sequence & Activity & Depth $(\mathrm{m})$ \\
\hline 1 & Installation of earth retaining support system & -5.1 \\
2 & Excavation process & -4.5 \\
3 & Install the first optimum servo steel support & -8.1 \\
4 & Excavation process & -7.5 \\
5 & Install the second optimum servo steel support & -11.1 \\
6 & Excavation process & -10.5 \\
7 & Install the third optimum servo steel support & -14.1 \\
8 & Excavation process & -13.5 \\
9 & Install the fourth optimum servo steel support & -16.5 \\
10 & Excavation process to formation level & \\
\hline
\end{tabular}

Figure 18(a) shows the measured maximum ground surface settlement on ZQT21 of $1.85 \mathrm{~mm}$ at $4 \mathrm{~m}$ distance, which got to zero at $12.5 \mathrm{~m}$ behind ZQT21 wall. The maximum ground surface settlement on ZQT12 was $2.8 \mathrm{~mm}$ at $4 \mathrm{~m}$ distance, which reached zero at $14.9 \mathrm{~m}$ behind ZQT12 wall, as shown in Figure 18(b). The more ground surface 


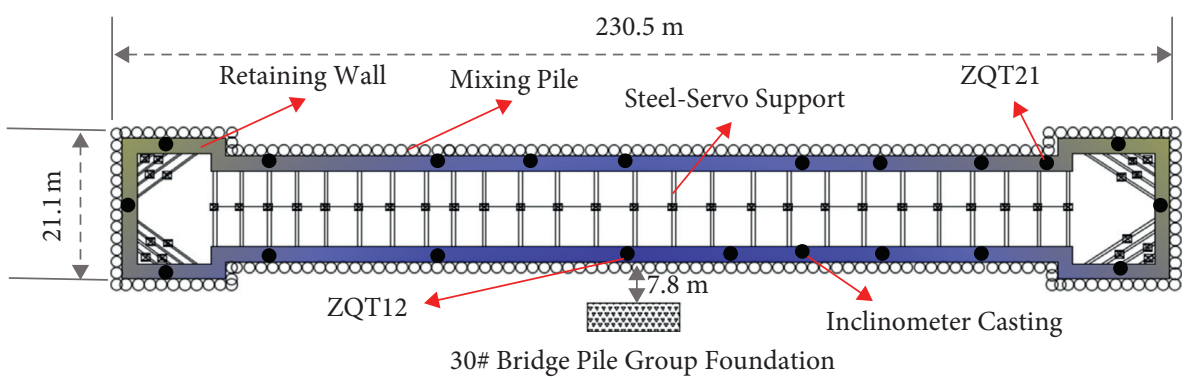

FIGURE 16: Shenzhen Line 12 subway station excavation pit profile showing the plan view and inclinometer castings for monitoring purpose.

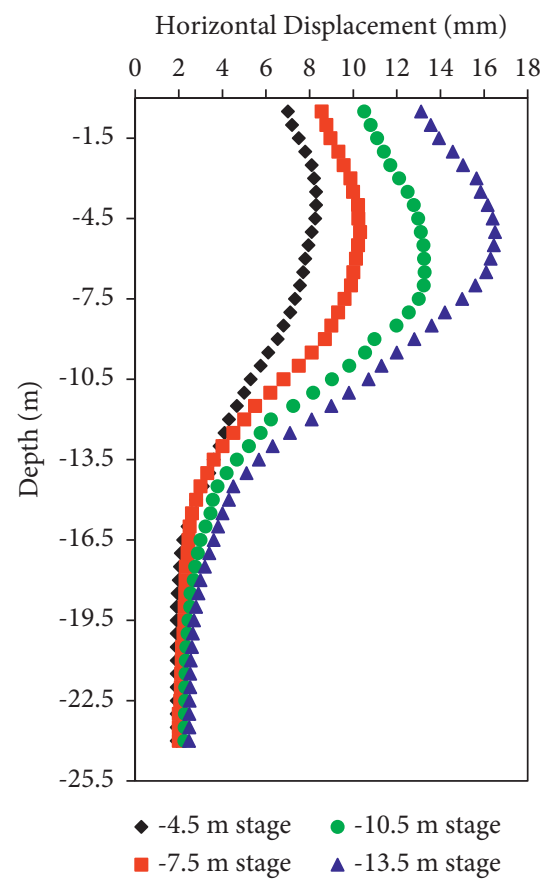

(a)

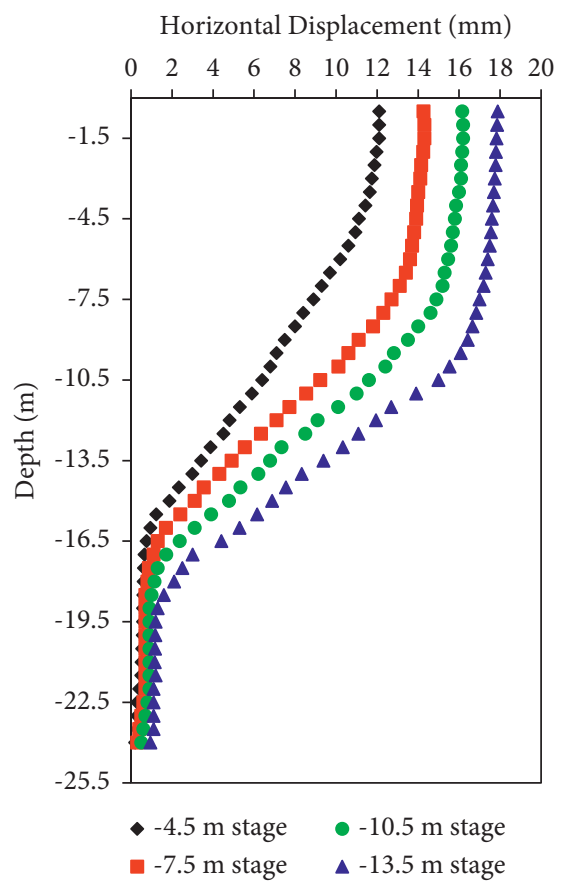

(b)

FIGURE 17: Influence of the optimum servo steel axial loading capacity application on cumulative horizontal displacement at the actual site. (a) ZQT21. (b) ZQT12.

influence zone settlement behind ZQT12 can be attributed to the project site working loading condition close to ZQT12 inclinometer point. Some of the construction materials were stockpiled near ZQT12 inclinometer, eventually experiencing more ground surface settlement from the additional loading. However, the ground surface influence zone settlements on both ZQT12 and ZQT21 were restrained within the project acceptable warning limits with the application of the optimum servo steel axial loading capacities.

Comparatively, the measured field data at SMRTL_12 was consistent with the calculated numerical model data. Prior numerical simulation provided a superior site working conditions. First, it helped in the speedy execution of actual excavation works, since the steel servo axial load support capacity was known beforehand. Errors on the project were significantly reduced, since the optimum construction sequence of field works was known in advance. Project execution safety standards were improved, since the excavation pit and the surrounding environment relative deformations caused by excavation were known prior to actual works. The obtained results clearly justified the use of PLAXIS 3D numerical simulation solutions for field excavation site servo geotechnology enhanced support application.

\section{Analysis of Triumph Unit Basement Excavation Project: A Case of Field Study}

4.1. Project Description. Another field excavation study application of servo steel enhanced support geotechnology was a deep foundation pit of Triumph Unit, FG25-R21-18 Jing-fang demolition resettlement house and the west side G1-35B park green space project in Hangzhou city, Zhejiang Province, China. This case was preferred for analysis because it provided a first-hand information of the real-time direct application of the servo method. The TU building block basement was internally supported with a hydraulic servo 


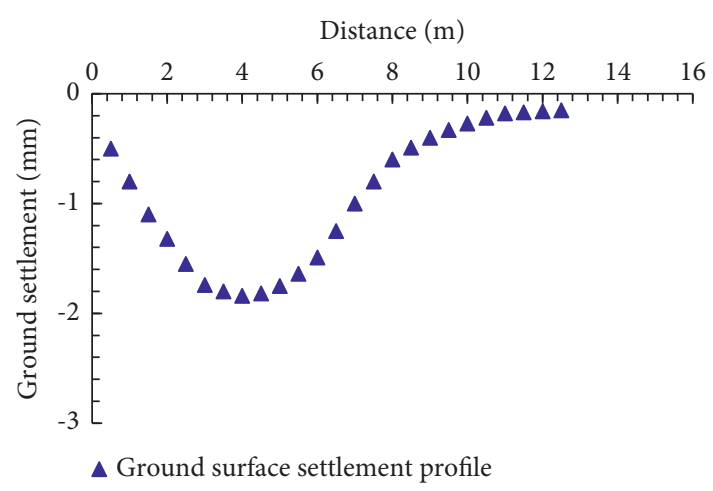

(a)

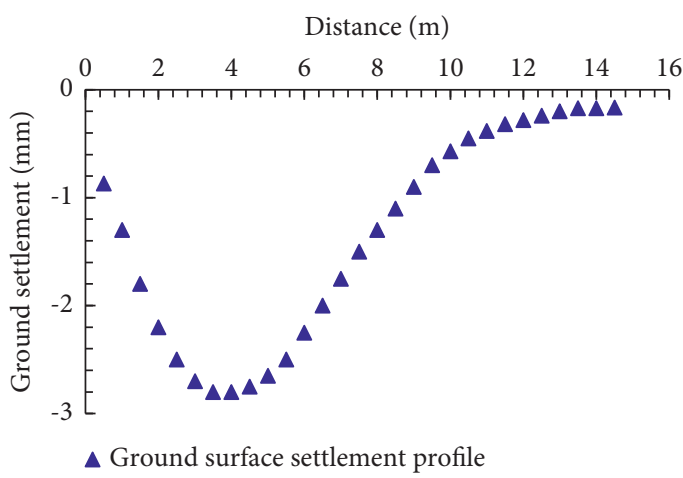

(b)

FIGURE 18: Influence of the optimum servo steel axial loading capacity application on ground surface influence zone settlement profile at the actual site. (a) ZQT21. (b) ZQT12.

steel bracing system, and the servo loadings were applied, adjusted, and optimised directly at the construction site during the project construction.

The project excavation pit was a braced, wide-pentagonshaped underground excavation with a depth of $14.2 \mathrm{~m}$ and standard area of $2334.5 \mathrm{~m}^{2}$. It was located within the enclave of existing high-rise residential buildings and a high traffic highway. Figure 19 shows the project site location and the surrounding environment. Furthermore, there were many existing facilities at the proposed project site, as shown in Figure 20. The existing buildings were demolished and levelled completely. The underground fuel gas tanks were relocated to a $207 \mathrm{~m}$ nearby gas station with all necessary precautions taken accordingly [30].

Soil samples were obtained from the site by the drilling and sample survey method. A total of 15 machine drill holes were arranged at the sides and corners of the project site [28]. Laboratory soil tests such as Atterberg limit, plasticity index, California bearing ratio as well as the in-situ dynamic penetrometer test, standard penetration test, and single-hole shear wave velocity test were carried out on the soil samples. The soil strata at the project construction site were primarily of soft clay according to the test results. Figure 21 shows the project site soil parameter layers' name, depth, unit weight $\gamma$ $\left(\mathrm{kN} / \mathrm{m}^{3}\right)$, cohesive force $c(\mathrm{kPa})$, stiffness Eur in $(\mathrm{MPa})$, internal friction angle $f\left({ }^{\circ}\right)$, and the unit less Poisson ratio v, within the first $29.50 \mathrm{~m}$ retaining wall soil depth.

Because of the strict requirement for protection of project site surroundings, the required project construction standards were stipulated and followed during the actual works. One of the project construction stipulated standards specified the warning limit for both wall lateral displacement and ground surface settlement to not exceed $0.21 \%$ of $\mathrm{H}$ $(14.2 \mathrm{~m}$; representing $30 \mathrm{~mm})$. The stipulated standards also limited ground surface settlement influence zone to $1.41 \%$ of $\mathrm{H}(14.2 \mathrm{~m}$; representing $20 \mathrm{~m})$. The project standards conformed to various technical codes for deep excavation pit construction and surrounding environment safety in Zhejiang Province and surrounding cities [22-27, 31].
Monitoring instruments such as inclinometers were placed on surrounding buildings to ensure their safety while the project was being carried out. The various wall lateral displacements and ground movements were monitored to ensure safety.

4.2. Triumph Unit Excavation Pit Support Structure Construction. The excavation pit retaining wall included the thermal-reactive diffusion (TRD) interpolated H700 steel pile wall. The pile wall had a maximum depth of $29.50 \mathrm{~m}$. The pile type was a section steel. The steel grade was Q235 with a material parameter of $\mathrm{HN} 700 \times 300$. The compression, shear, and bending resistance of the pile wall was $215 \mathrm{MPa}$. Its plastic development coefficient was 1.05. Figure 21 shows a cross-sectional view of the excavation pit section support.

Three internal steel bracing support levels were constructed. The steel bracing support had $800 \mathrm{~mm}$ diameter with $16 \mathrm{~mm}$ thickness and was diagonally spaced $5 \mathrm{~m}$ apart at the corners of each elevation. The steel bracing vertical spacing was $1.60 \mathrm{~m}, 4.50 \mathrm{~m}$, and $3.50 \mathrm{~m}$, respectively. All the three steel bracing supports were preloaded with $1520 \mathrm{kN}$ axial loading capacity. The steel stiffness was $500 \mathrm{MN} / \mathrm{m}$, with a resistance of $9000 \mathrm{kN}$, and the adjustment coefficient was 1.0. The steel bracing supports had movable ends for prestress application and were erected at $-1.60 \mathrm{~m},-6.10 \mathrm{~m}$, and $-9.60 \mathrm{~m}$ elevations. At each erection stage, the steel support was incorporated with the hydraulic servo system to enhance the steel bracing lateral support mechanism. Table 6 details the actual basement excavation and support structure construction sequences.

\subsection{Triumph Unit Field Monitoring Results}

4.3.1. Wall Lateral Displacement. The measured field works were examined for three different application cases of servo steel bracing axial loading capacities, with the excavation profile unchanged in all three cases. 


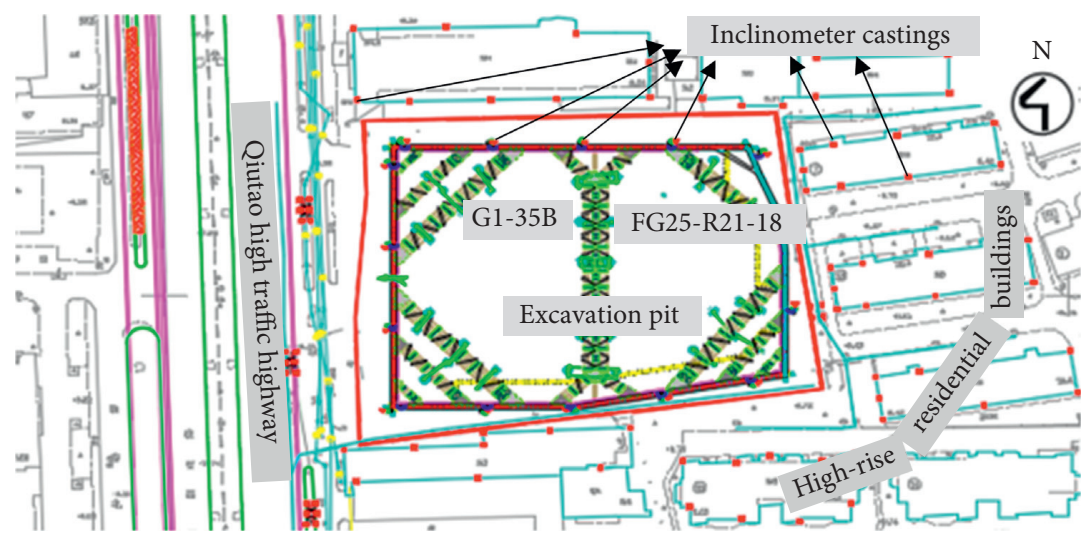

FIGURE 19: Triumph Unit project plan view showing the excavation pit, surrounding environment, and the inclinometer points for monitoring purpose.

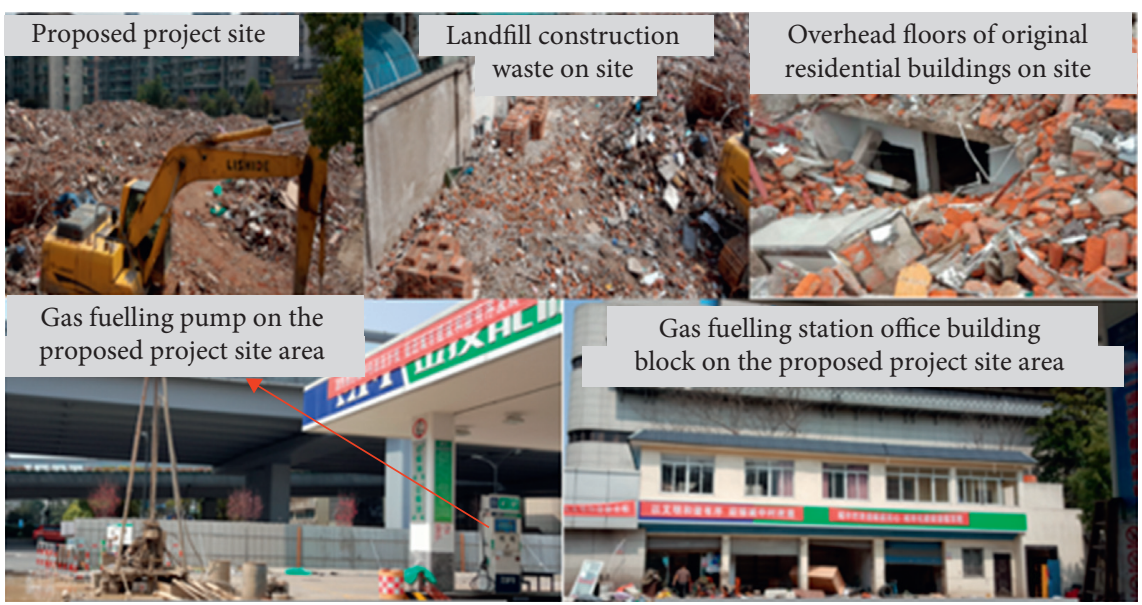

FIgURE 20: Triumph Unit construction site showing the environmental condition of the site topography and landforms prior to commencement of basement excavation.

In the first case, steel bracing with a predefined axial load of $1520 \mathrm{kN}$ was applied in all elevations at $-1.6 \mathrm{~m},-6.1 \mathrm{~m}$, and $-9.6 \mathrm{~m}$. The measured maximum displacements were $27 \mathrm{~mm}, 44 \mathrm{~mm}$, and $61 \mathrm{~mm}$ at $-1.6 \mathrm{~m},-6.1 \mathrm{~m}$, and $-9.6 \mathrm{~m}$ elevations, respectively, as demonstrated in Figure 22(a). The obtained displacement data satisfied the limit of displacement of $0.21 \%$ of $\mathrm{H}(14.2 \mathrm{~m}$; representing $30 \mathrm{~mm})$ at $-1.6 \mathrm{~m}$ stage. As the excavation depth increased, this limit was exceeded. This was confirmed by the results at depths of $-6.1 \mathrm{~m}$ and $-9.6 \mathrm{~m}$.

In the second case, a servo loading with $640 \mathrm{kN}$ capacity was incorporated at depths of $-6.1 \mathrm{~m}$ and $-9.6 \mathrm{~m}$ where the predefined steel bracing with $1520 \mathrm{kN}$ axial load was erected. This made the total load applied at $-6.1 \mathrm{~m}$ and $-9.6 \mathrm{~m}$ stages in the second case increased to $2160 \mathrm{kN}$ capacity. The predefined steel stiffness with $1520 \mathrm{kN}$ axial load was left unchanged at $-1.6 \mathrm{~m}$ elevation. Then, the measured maximum displacements became $9 \mathrm{~mm}, 22 \mathrm{~mm}$, and $37 \mathrm{~mm}$ for all three elevations, as shown in Figure 22(b). The displacement measurement was above the project allowable limit at $-9.6 \mathrm{~m}$ elevation.
In the third case, the $640 \mathrm{kN}$ servo load applied at $-9.6 \mathrm{~m}$ stage where the incurred displacement exceeded the required limit was adjusted with another servo load of a greater capacity of $860 \mathrm{kN}$. The servo loading with $640 \mathrm{kN}$ capacity was still incorporated at $-6.1 \mathrm{~m}$ elevation. The predefined steel bracing with $1520 \mathrm{kN}$ axial load was maintained in all support elevations. This eventually made the total support axial loading of $1520 \mathrm{kN}$ at $-1.6 \mathrm{~m}$ stage, $2160 \mathrm{kN}$ at $-6.1 \mathrm{~m}$ stage, and $2380 \mathrm{kN}$ at $-9.6 \mathrm{~m}$ stage. After support erection, the measured displacements were $6 \mathrm{~mm}, 10 \mathrm{~mm}$, and $16 \mathrm{~mm}$ at $-1.6 \mathrm{~m},-6.1 \mathrm{~m}$, and $-9.6 \mathrm{~m}$ stages, respectively, as depicted in Figure 22(c). The maximum displacement was $0.11 \%$ of $\mathrm{H}(14.2 \mathrm{~m}$; representing $16 \mathrm{~mm})$ at $-9.0 \mathrm{~m}$ depth when the excavation earthwork was advanced to $-9.6 \mathrm{~m}$ elevation in the third case. The measurements were within the limit of $0.21 \%$ of $\mathrm{H}$ as required by the project standards. Compared with the measured maximum displacement in the first case, the displacement in the third case declined by $74 \%$, $77 \%$, and $78 \%$ at $-9.6 \mathrm{~m},-6.1 \mathrm{~m}$, and $-1.6 \mathrm{~m}$ excavation stages, respectively. Thus, the displacement reduced by $76 \%$ on average with servo steel enhanced support geotechnology 


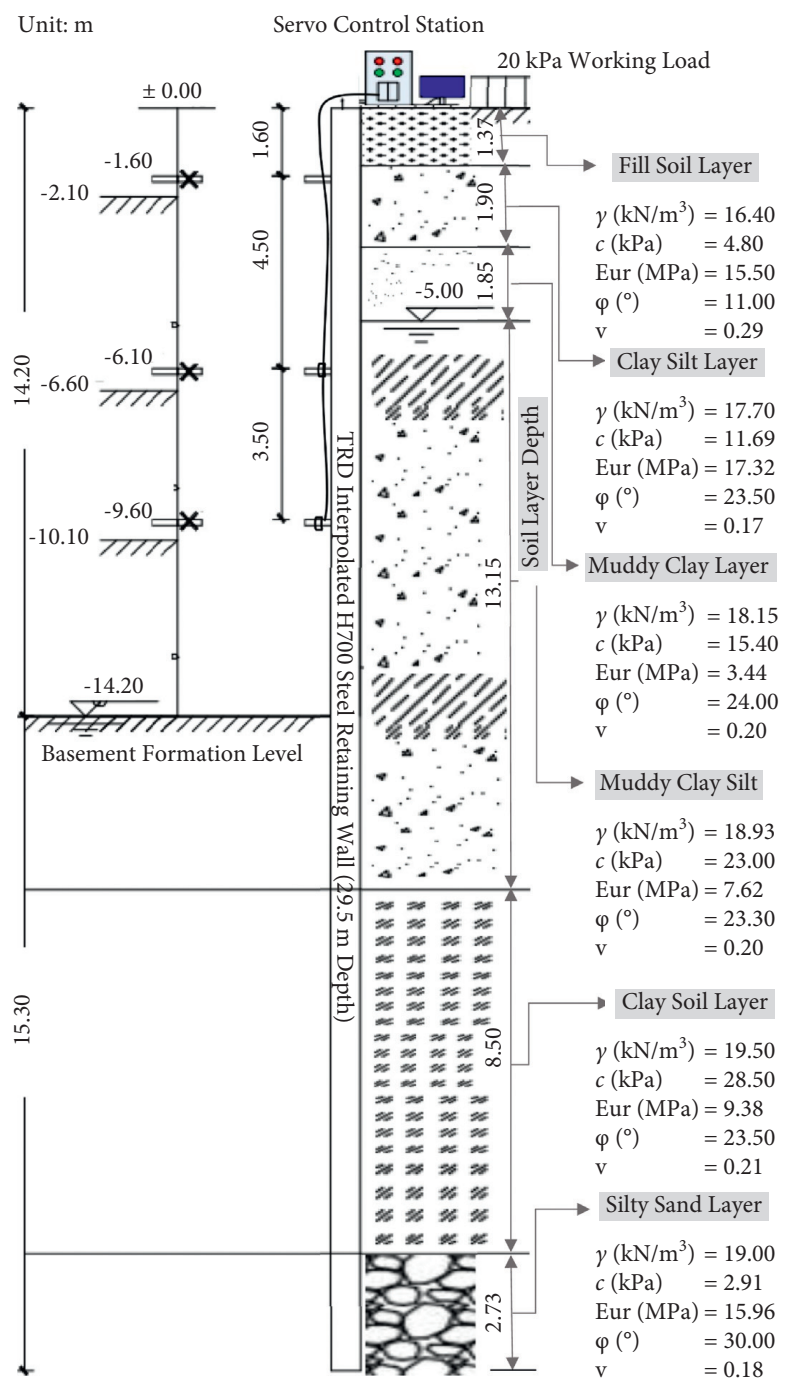

FIGURE 21: Triumph Unit building block basement excavation pit cross-sectional view.

TABLe 6: Triumph Unit excavation field works.

\begin{tabular}{lcc}
\hline Construction sequence & Activity & Depth (m) \\
\hline 1 & Install the earth retaining support structure & Excavation process \\
2 & Erect the first steel bracing support & -2.10 \\
3 & Add and optimise the servo load to the first steel support & -1.60 \\
4 & Excavation process & -1.60 \\
5 & Erect the second steel bracing support & -6.60 \\
6 & Add and optimise the servo load to the second steel support & -6.10 \\
7 & Excavation process & -6.10 \\
8 & Erect the third steel bracing support & -9.10 \\
9 & Add and optimise the servo load to the third steel support & -9.60 \\
10 & Excavation process to the basement formation level & -14.20 \\
11 & &
\end{tabular}

application. This field result was consistent with the previous findings of Di et al. [15].

From Figure 22, the displacements that were obtained in the first case were restrained adequately but not to the extent of meeting the project expected limit in all basement excavation stages. The obtained displacement satisfied the project allowable limit at $-1.6 \mathrm{~m}$ elevation. This finding agreed well with $\mathrm{Wu}$ et al. [9] determination which depicted that the steel support is effective for lateral support of shallow excavations. When estimated and applied appropriately, steel bracing support in shallow foundations reduces excavation-induced deformation as required [9]. 


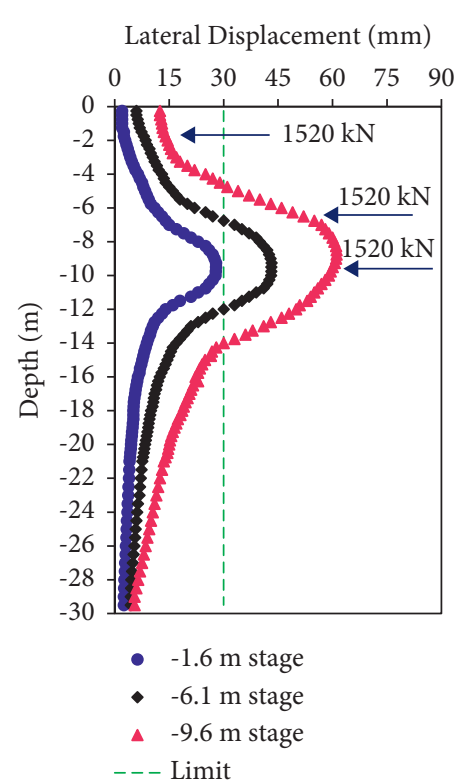

(a)

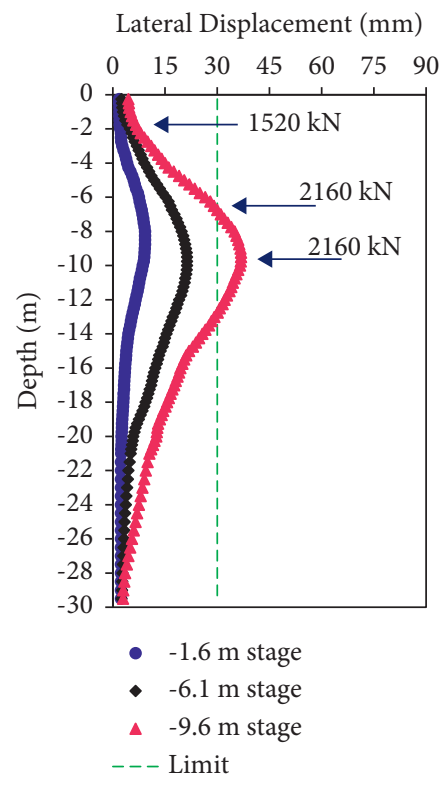

(b)

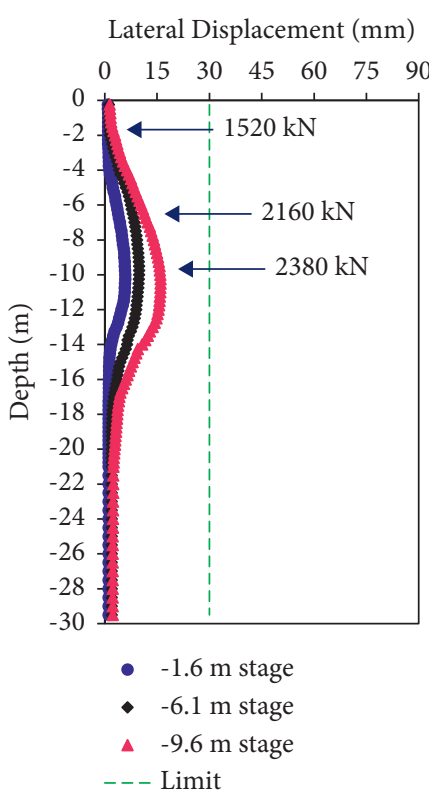

(c)

FIGURE 22: Influence of the application of steel and servo axial loading capacities on the profile of wall lateral displacement. (a) First case. (b) Second case. (c) Third case.

Moreover, with the incorporation of servo loading at $-6.1 \mathrm{~m}$ in the second case, the displacements were further restrained. The measurements were satisfactory for project required displacement limit at $-1.6 \mathrm{~m}$ and $-6.1 \mathrm{~m}$ elevations but not satisfactory at $-9.6 \mathrm{~m}$ elevation. With higher servo axial force application at $-9.6 \mathrm{~m}$ elevation in the third case, the displacements were controlled remarkably to meet the limit of displacement as required by the project standards. Hence, increasing the applied force in the servo steel bracing helped to limit the displacement induced by the excavation stage to meet the limit of required displacement. This showed that the larger the servo steel enhanced the axial load support application in subsequent basement pit elevations, the greater the wall lateral displacement reduction. Therefore, the servo geotechnology placed at deeper depth optimised the axial loading capacity and reduced the soil body displacement desirably.

4.3.2. Ground Surface Influence Zone Settlement. The influence of servo steel enhanced support geotechnology application on the profile of ground surface settlement was analysed at TU project site. This was done to investigate the servo steel method application effect on the surrounding environment relative deformation. Figure 23 shows the measured ground surface settlement profile for the steel and servo method application in the first, second, and third case scenarios.

From Figure 23, we can see that the maximum ground surface settlement was $8.5 \mathrm{~mm}$ (representing $0.061 \%$ of $\mathrm{H}$ ), $6.2 \mathrm{~mm}$ (representing $0.044 \%$ of $\mathrm{H}$ ), and $2.8 \mathrm{~mm}$ (representing $0.020 \%$ of $\mathrm{H}$ ) in the first, second, and third cases, respectively. The measured maximum ground surface settlement was within the acceptable project ground surface settlement limit of $0.21 \%$ of $\mathrm{H}$ (14.2 $\mathrm{m}$; representing $30 \mathrm{~mm})$ in all three cases. The ground surface settlement increased gradually as the excavation depth increased. The ground surface settlement in the third case dropped by $67 \%$ as compared with the measured ground surface settlement in the first case when the support was steel bracing alone. With higher servo load application in subsequent excavation elevations during the third case, the ground surface settlement declined significantly. This finding corroborated well with the determination of Ming-Guang et al. [18] during their numerical simulation measurements, which showed the effectiveness of servo support application on ground surface settlement control.

Furthermore, during the first case, the ground surface settlement increased up to a maximum value of $8.5 \mathrm{~mm}$ at a distance of $8.9 \mathrm{~m}$ away from the basement pit when the excavation earthwork was advanced to $-9.6 \mathrm{~m}$ stage, as shown in Figure 23(a). This confirmed that the ground surface settlement increases as excavation depth increases [32]. After the application of steel support alone, in all elevations in the first case, the ground surface settlement declined rapidly and got to zero at $22.9 \mathrm{~m}$ distance away from the excavation pit. This finding correlated well with the determinations of Liang et al. [5] and Wang [8], which described that the steel support alone in excavation is capable of reducing the ground surface influence zone to a certain degree. However, the measured ground surface settlement influence zone limit of $1.41 \mathrm{H}(14.2 \mathrm{~m}$; representing $20 \mathrm{~m}$ ) as required by this project was exceeded in the first case. 


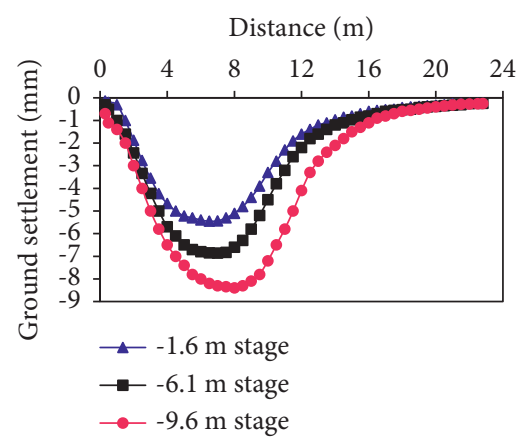

(a)

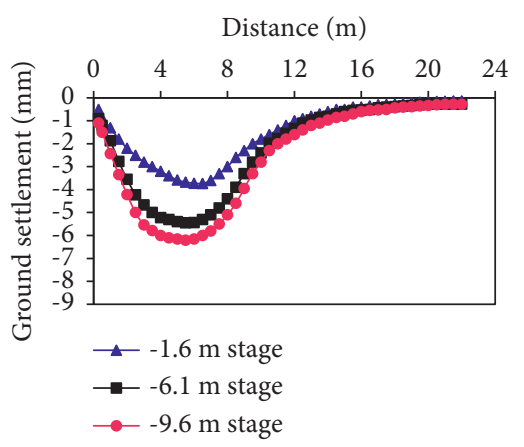

(b)

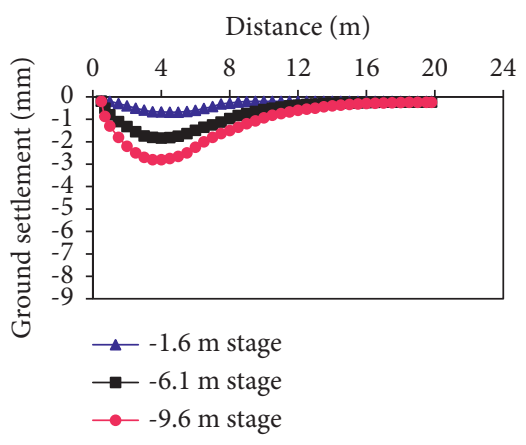

(c)

FiguRE 23: Influence of the application of steel and servo axial loading capacities on the profile of ground surface influence zone settlement. (a) First case. (b) Second case. (c) Third case.

In the second case, the maximum ground surface settlement occurred at $5.0 \mathrm{~m}$ distance during excavation to $-9.6 \mathrm{~m}$ elevation and reached zero at $22.0 \mathrm{~m}$ distance away from the excavation edge, as shown in Figure 23(b). As compared with the first case, the ground surface settlement influence zone reduced by $0.9 \mathrm{~m}$ from $22.9 \mathrm{~m}$ to $22.0 \mathrm{~m}$. The effect of servo load application at $-6.1 \mathrm{~m}$ stage in the second case on ground surface settlement influence zone control was unnoticeable and minimal. The project stipulated a ground surface settlement influence zone limit of $1.41 \mathrm{H}$ which was exceeded.

With the application of higher servo load capacity at a subsequent deeper elevation of $-9.6 \mathrm{~m}$ in the third case, the ground surface settlement influence zone reduced by $5.1 \mathrm{~m}$ from $22.9 \mathrm{~m}$ to $17.8 \mathrm{~m}$ (compared with the first case) and by $4.2 \mathrm{~m}$ from $22.0 \mathrm{~m}$ to $17.8 \mathrm{~m}$ (compared with the second case). The maximum ground surface settlement occurred at $4.0 \mathrm{~m}$ distance and got to zero at $17.8 \mathrm{~m}$ distance behind the wall, as depicted in Figure 23(c). Moreover, the ground surface settlement influence zone result in the third case was restrained greatly within the acceptable limit of $1.41 \mathrm{H}$ $(14.2 \mathrm{~m}$; representing $20 \mathrm{~m}$ ) as required by the project. This implies that the incorporation of higher servo load capacity in the third case played a remarkable role in the ground surface influence zone settlement control.

Unlike the first SMRTL_12 subway station excavation project where the prior numerical simulation provided beforehand site working experience, at TU excavation project, some lapses were exposed in the direct application of the servo method on-site without prior numerical simulations. The exact needed servo axial load support was not known in advance; hence, there is the need to apply trial servo loads. If the servo load was overestimated and applied, the localised punching damage on the support structure would have occurred [32]. Therefore, the general method of application as used at this project was to start from a lower servo load as estimated by the project engineers and increase it gradually until the displacement was within the limits for the support walls. This method could have also posed a risk of having irrecoverable displacements on supported walls and settlements on existing structures within the influence areas beyond the required limits [30]. Nonetheless, the direct application of the servo geotechnology at TU project site restrained the displacement of the excavation on-site desirably. The application of the servo steel geotechnology in both projects was beneficial. The excavation-induced deformations were restrained within the respective project acceptable warning limits, the safety of surrounding environment was ensured, and both projects were completed successfully.

Moreover, the results from the two projects validated well with the servo numerical simulation application results from previous studies of Di et al. [15], Ming-Guang et al. [18], and Sun [19]. Specifically, Ming-Guang et al. [18] study restrained the wall displacement to $95 \mathrm{~mm}$ and ground surface settlement influence zone to $60 \mathrm{~m}$ distance behind an excavation pit of depth $19.7 \mathrm{~m}$ maximum. This was achieved after application of $2600 \mathrm{kN}$ and $4000 \mathrm{kN}$ servo load capacities at the middle and final excavation stages, respectively. Similarly, a research conducted by $\mathrm{Di}$ et al. [15] observed that a $24.8 \mathrm{~m}$ deep excavation pit, which was supported with a servo system, controlled the wall displacement by $71 \%$ on average. It reduced the ground surface settlement by $62 \%$ on average and limited the maximum ground surface settlement influence zone to $15 \mathrm{~m}$ away from the excavation pit. This was achieved in comparison with the measurements of the section of the same pit which was supported with steel bracing alone. In their conclusion, Di et al. [15] stated that the incorporation of higher servo load capacity of more than $2131.5 \mathrm{kN}$ in later subsequent excavation stages controlled the displacements efficiently in the section that was supported with a servo system. A study conducted by Sun [19] concluded that employing higher servo axial loading capacity at depths of more than $10 \mathrm{~m}$ during the excavation process results in greater displacement reduction by up to more than $60 \%$ compared with employing steel bracing support alone. Thus, the present numerical simulation literature data substantiate well with both SMRTL_12 subway station and TU basement construction field data. They all demonstrate the strong capacity of servo steel enhanced support geotechnology in restraining the deformation caused by excavation. 


\section{Conclusion}

This paper discussed the results of two case studies on the application of hydraulic servo enhanced lateral support on deep excavation. The SMRTL_12 subway station and TU high-rise building basement excavations served as the practical application of the servo axial load enhancement support system on the actual construction projects. The difference of the first and second field projects was based on the method of application of the hydraulic servo. The main work from this study is summarized as follows:

(1) On the SMRTL_12 subway station project, the servo axial loading capacities were first simulated and optimised in a numerical model. Then, the optimum servo axial loads were adopted and applied during the actual construction. On the TU high-rise building basement project, the servo axial loading capacities were applied and adjusted directly at the construction site during the construction process.

(2) Servo steel enhanced support geotechnology deep basement internal support application was able to increase the load carrying capacity of the support structures at various levels of excavations. The stiffness of the support structure was increased by the application of the hydraulic servo.

(3) With the application of servo load capacities to the two field case studies, the deep basement excavation induced cumulative displacements were kept within the limit of displacements as required by each respective project. Specifically, the measured maximum wall displacement of TU high-rise building block basement excavation was reduced by up to $76 \%$ on average.

(4) Comparing the SMRTL_12 calculated numerical model results with the measured field data, the prior numerical simulation of the required servo capacity provided an efficient site working condition by increasing the safety on both the project and the $7.8 \mathrm{~m}$ adjacent 30\# bridge pile group foundation from the effect of the excavationinduced deformations. The works involved with the use of servo on-site were significantly reduced. Hence, the application of numerical simulation before actual field works was justified.

(5) The measured data at the TU field project demonstrated that the servo steel axial loading support enhancement geotechnology is a suitable option for application to actual construction of deep excavation projects with strict deformation control requirements. This actual construction application validated previous research works based on numerical simulations.

(6) This research could not substantiate the effect of servo steel enhanced excavation pit support pre- or postloading on the displacement of the excavation. It is recommended that future works could investigate this phenomenon to optimise the servo geotechnology field construction site application process.

\section{Data Availability}

The data used to support the findings of this study are included within the article.

\section{Conflicts of Interest}

The authors declare that there are no conflicts of interest regarding the publication of this paper.

\section{Acknowledgments}

This work was supported by the Shenzhen Metro Group Co., Ltd., China, and Archtectural Design Research Institute of Zhejiang University. Their support is greatly acknowledged.

\section{References}

[1] L. Y. Ding, X. G. Wu, H. Li, H. B. Luo, and Y. Zhou, "Study on safety control for Wuhan metro construction in complex environments," International Journal of Project Management, vol. 29, no. 7, pp. 797-807, 2011.

[2] J. Liu, "Monitoring and analysis of ultra-wide and deep foundation pit deformation in complex environment," IOP Conference Series: Earth and Environmental Science, vol. 295, no. 2, 2019.

[3] G. M. B. Viggiani, A. Mandolini, A. Flora, and G. Russo, "Excavations in the urban enviroment: examples from the construction of napoli underground," in Proceedings of the Int. Conference on Geotechnical Challenges in Megacities, pp. 236-258, Moscow, Russia, 2021.

[4] L. Song-Shun, S. Shuilong, Z. Annan, and Z. Ning, "Ensemble model for risk status evaluation of excavation," Automation in Construction, vol. 132, 2021.

[5] R. Liang, J. Wu, L. Sun, W. Shen, and W. Wu, "Performances of adjacent metro structures due to zoned excavation of a large-scale basement in soft ground," Tunnelling and Underground Space Technology, vol. 117, 2021.

[6] L. Song-Shun, Z. Ning, Z. Annan, and S. Shuilong, "Timeseries prediction of shield movement performance during tunnelling based on hybrid model," Tunnelling and Underground Space Technology, vol. 119, 2021.

[7] J. Shi, G. Liu, P. Huang, and C. W. W. Ng, "Interaction between a large-scale triangular excavation and adjacent structures in Shanghai soft clay," Tunnelling and Underground Space Technology, vol. 50, pp. 282-295, 2015.

[8] W. Wang, "Inspection test and analysis of axial force in steel brace during construction of foundation pit in running tunnel section adjacent to Liming Cultural Club station of Shenyang Metro," Railway Engineering, vol. 4, pp. 86-88, 2007.

[9] J. Wu and W. Yanxia, "Axial force monitoring and analysis of the steel foundation of deep foundation pit of Hangzhou Qiutao Road Metro Station," Railway Construction, vol. 53, no. 10, pp. 51-54, 2013.

[10] C. Moormann and H. Moormann, "Study of wall and ground movements due to deep excavation in soft soil based on worldwide experiences," Geotechnical Aspects of Underground Construction in Soft Ground, Toulouse Spécifique, Lyon, 2002.

[11] S. M. Zhang, T. K. Yuan, and W. G. Liu, "Application of axial force compensation for steel support system in practical 
project," Applied Mechanics and Materials, vol. 477-478, pp. 503-508, 2013.

[12] M. V. Nicotera and G. Russo, "Monitoring a deep excavation in pyroclastic soil and soft rock," Tunnelling and Underground Space Technology, vol. 117, Article ID 104130, 18 pages, 2021.

[13] A. Benin, A. Konkov, V. Kavkazskiy, A. Novikov, and N. Vatin, "Evaluation of deformations of foundation pit structures and surrounding buildings during the construction of the second scene of the state academic mariinsky theatre in saint-petersburg considering stage-by-stage nature of construction process," Procedia Engineering, vol. 165, pp. 1483-1489, 2016.

[14] R. N. Hwang and L. W. Wong, "Effects of preloading of struts on retaining structures in deep excavations," Geotechnical Engineering, vol. 49, no. 2, pp. 104-114, 2018.

[15] H. Di, H. Guo, S. Zhou, J. Chen, and L. Wen, "Investigation of the axial force compensation and deformation control effect of servo steel struts in a deep foundation pit excavation in soft clay," Advances in Civil Engineering, vol. 2019, Article ID 5476354, 16 pages, 2019.

[16] Y. Fang, L. Zhiren, and W. Jin, "Research on safety support technology for ultra-deep foundation pit based on supporting servo combined system," Tunnel Construction, vol. 39, pp. 120-128, 2019.

[17] J. Jia, X. L. Xie, and F. Y. Luo, "Support axial force servo system in deep excavation deformation control." Journal of Shanghai Jiaotong University, vol. 43, pp. 1589-1594, 2009.

[18] L. Ming-Guang, D. Olivier, and C. Jin-Jian, "Effectiveness of servo struts in controlling excavation-induced wall deflection and ground settlement," Acta Geotechnica, vol. 15, pp. 2575-2590, 2020.

[19] J. Sun, "Research on the setting method of the steel support axial force servo system for subway foundation pits," Chinese Journal of Underground Space and Engineering, vol. 15, pp. 195-204, 2019, z1.

[20] S. Ye, Z. Zhao, and D. Wang, "Deformation analysis and safety assessment of existing metro tunnels affected by excavation of a foundation pit," Underground Space, vol. 6, 2020.

[21] G. Bian, "Research on some problems and countermeasures of steel support servo system application," Shanxi Architecture, vol. 44, no. 15, pp. 70-71, 2018.

[22] Dbj/T15-120-2017, "Technical code for protection of exisiting structures of urbarn rail transit," Guangzhou- Housing and Urban-Rural Construction Department of Gwangdong Province, China, 2017.

[23] Gb 50497-2009, "Technical specifications for construction foundation pit engineering monitoring," in The Professional Standards Compilation Group of People's Republic of ChinaBeijing, China, 2009.

[24] Gb 50007-2012, "Code for design of building foundation engineering," The Professional Standards Compilation Group of People's Republic of China, Beijing, China, 2012.

[25] Jgj 94-2008, "Technical specifications for building pile foundation," Requirement of Chineses Standards, China, 2008.

[26] Gb 50911-2013, "Code for monitoring measurement of urban rail transit engineering," in The Professional Standards Compilation Group of People's Republic of ChinaBeijing, China, MOHURD (Ministry of Housing and Urban-ural Development of the People's Republic of China, Beijing, China, 2013.

[27] Gb 5007-2011, "Code for design of building foundation," MOHURD (Ministry of Housing and Urban-Rural Development of the People's Republic of China, Beijing, China, 2011.

[28] Jgj87-2012, "Industry standard: technical specifications for geological exploration and sampling of construction engineering," MOHURD (Ministry of Housing and Urbanural Development of the People's Republic of China, Beijing, China, 2012.

[29] M. Batten, W. Powrie, R. Boorman, H. T. Yu, and Q. Leiper, "Use of vibrating wire strain gauges to measure loads in tubular steel props supporting deep retaining walls," Proc. Inst. Civ. Eng. Geotechnical Eng, vol. 137, no. 1, pp. 3-13, 2015.

[30] Gb 50046-2008, National Standard: Code for Anticorrosion Design of Industrial Buildings, China Construction Standards, Beijing, China, 2008.

[31] Db33/T 1096-2014, Zhejiang Province Construction Foundation Pit Engineering Technical SpecificationChina Construction Standards, Beijing, China, Chinese, 2014.

[32] W. Charles, H. Y. Erin, and W. Leung, "Wall and ground movements associated with deep excavations supported by cast in situ wall in mixed ground conditions," Journal of Geotechnical and Geoenvironmental Engineering, vol. 133, no. 2, pp. 129-143, 2007.

[33] J. Zhou and G. Fang, "Design and construction monitoring and deformation analysis of super-large deep foundation pit," IOP Conference Series: Materials Science and Engineering, vol. 652, no. 1, pp. 0-7, 2019. 